\title{
Nutrition Care Practices of Dietitians and Oral Health Professionals for Oral Health Conditions: A Scoping Review
}

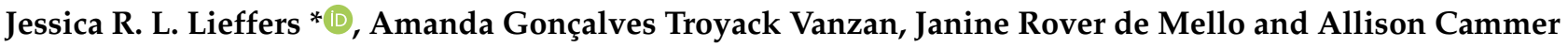 \\ College of Pharmacy and Nutrition, University of Saskatchewan, Saskatoon, SK S7N 5E5, Canada; \\ agv665@usask.ca (A.G.T.V.); jar018@usask.ca (J.R.d.M.); allison.cammer@usask.ca (A.C.) \\ * Correspondence: jessica.lieffers@usask.ca
}

Citation: Lieffers, J.R.L.; Vanzan, A.G.T.; Rover de Mello, J.; Cammer, A. Nutrition Care Practices of Dietitians and Oral Health Professionals for Oral Health Conditions: A Scoping Review. Nutrients 2021, 13, 3588. https://doi.org/10.3390/nu13103588

Academic Editors: Kirstin Vach and Johan Peter Woelber

Received: 15 September 2021

Accepted: 2 October 2021

Published: 13 October 2021

Publisher's Note: MDPI stays neutral with regard to jurisdictional claims in published maps and institutional affiliations.

Copyright: (c) 2021 by the authors. Licensee MDPI, Basel, Switzerland. This article is an open access article distributed under the terms and conditions of the Creative Commons Attribution (CC BY) license (https:// creativecommons.org/licenses/by/ $4.0 /)$.

\begin{abstract}
Background: Oral health conditions, such as dental caries, pose a substantial burden worldwide. Although there are many risk factors for poor oral health, diet is often implicated as a cause of these issues. The purpose of this scoping review was to identify and map studies that have captured information on the "real-world" nutrition care practices of oral health professionals (OHPs) and dietitians to optimize oral health, and specifically the dentition and periodontium. Methods: A search of peer-reviewed articles was conducted using MEDLINE, CINAHL, and Embase. Articles that addressed the review objective and met the following criteria were included: English language, published since 2000, and study conducted in a high-income country. Results: Overall, 70 articles were included. Most articles reported on cross-sectional survey studies and provided self-reported data on OHP practices; few articles reported on dietitians. Most articles reported only general/unspecific information on assessment and intervention practices, such as dietary analysis, nutrition counselling, and diet advice, and lacked specific information about the care provided, such as the dietary assessment tools used, type of information provided, and time spent on these activities. Barriers to the provision of nutrition care by OHPs were common and included time and lack of remuneration. Few studies reported on collaboration between dietitians and OHPs. Conclusions: Several studies have captured self-reported information on nutrition care practices of OHPs related to oral health; however, there is limited information available on the details of the care provided. Few studies have examined the practices of dietitians.
\end{abstract}

Keywords: oral health; dental caries; diet therapy; dentists; dental auxiliaries; nutritionists; dietitian; surveys and questionnaires; qualitative research; review

\section{Introduction}

Worldwide, oral health issues (e.g., dental caries, periodontal disease) affect 3.5 billion people [1], with dental caries being the most common concern [2]. Oral health issues also affect many people in Canada. For example, the 2007-2009 Canadian Health Measures Survey (CHMS) reported that 57\%, 59\%, and 96\% of 6-11-year-olds, $12-19$-year-olds, and adults, respectively, had experienced dental caries [3]. Dental caries are also the most common reason for day surgery in children 12-59 months of age in Canada [4]. Periodontal issues are also common in Canada; according to the 2007-2009 CHMS, 21\% of adults with teeth were found to have or previously had moderate or severe periodontal issues [3]. Various factors can affect the risk of oral health issues, including fluoride, oral hygiene (e.g., brushing, flossing), tobacco, and diet [5].

More specific to diet, both the physical and chemical properties of the foods we eat, as well as how the foods we eat are consumed (e.g., frequency, delivery) can have protective or detrimental effects on oral health (and specifically the dentition and periodontium) [6]. Fermentable carbohydrates (e.g., sucrose) have a known relationship with dental caries [7]; however, the relationship between oral health and diet is much more extensive [8]. For example, hard cheese; sugar alcohols (e.g., xylitol); diets rich in vegetables, fruits, whole 
grains, and high-quality proteins; and adequate spacing between eating occasions are thought to be protective against dental caries [6,8,9]. Acidic foods and beverages have also been previously linked with tooth erosion $[10,11]$. The relationship between diet and oral health has been summarized in several articles [6,8-10,12-17], and some organizations have released statements and guidelines on this topic [8,18-20]. We also know that many people in Canada have diet behaviours associated with poor oral health (e.g., high intakes of sugar-sweetened beverages [21]). In addition to diet being linked to various oral health issues, poor oral health can also have nutritional implications (e.g., children with early childhood caries can experience difficulties eating [22]). Importantly, the relationship between nutrition and oral health is important throughout the entire human lifespan $[8,12]$.

The provision of nutrition care to optimize oral health is within the scope of practice of different health professions including dietitians and oral health professionals. In addition, healthy eating has been identified as a priority area by the World Health Organization when initiating and strengthening oral health programs $[23,24]$. To date, information on the current "real-world" practices regarding nutrition care for oral health (and specifically the dentition and periodontium) provided by dietitians and oral health professionals has been captured in different types of studies with different focuses; however, reviews on this topic are limited. A previous review article published in 2014 examined the diet advice practices of oral health professionals, including variables that influence this activity [25]. Since this article has been published, there have been several other relevant studies that have emerged. This article also did not examine the practices of dietitians.

The purpose of this scoping review is to identify and map current studies that have captured information on the "real-world" nutrition care practices of oral health professionals and dietitians to optimize oral health (specifically the dentition and periodontium), in addition to collaboration between the two professions. We wanted to capture information on the scope of the literature addressing this topic and consolidate the wide range of studies to identify gaps in the literature to understand how to move this area of research forward. This project lends itself well to a scoping review because of the diversity of studies and study designs that have investigated this topic. This review did not seek to investigate the impact of different types of nutrition care practices on oral health.

\section{Materials and Methods}

The scoping review framework outlined by Arksey and O'Malley [26] was used to guide this review. In addition, the article by Levac et al. [27] was also used to help guide this review. The five steps that were followed to conduct this review are outlined below. A review protocol does not exist for this scoping review.

Stage 1: Research Question Development

The first component of conducting a scoping review is to identify the research question that will be investigated. The question that was used to guide the review was as follows: What is reported in the literature about the "real-world" practices of dietitians and oral health professionals regarding nutrition care for oral health (and specifically conditions that affect the dentition and periodontium)? In addition, we were also interested in understanding what has been studied regarding collaboration between the two professions for this purpose. According to the FDI World Dental Federation definition, "oral health is multi-faceted and includes the ability to speak, smile, smell, taste, touch, chew, swallow and convey a range of emotions through facial expressions with confidence and without pain, discomfort and disease of the craniofacial complex (head, face, and oral cavity)" [28]. We were specifically interested in studies focusing on the health of the dentition and periodontium. A scoping review for this research question is suitable as we were interested in understanding the range of the evidence to date, and because there are numerous possible study designs that could address the research question. The purpose of this review is to help to summarize the extent and nature of the research activity in this area. This review will help to identify and clarify research needs to help advance the area of nutrition 
care and oral health (specifically conditions that affect the dentition and periodontium) to help decrease the burden of oral diseases in Canada and beyond.

Stage 2: Identification of Relevant Studies

A literature search was conducted using the MEDLINE, CINAHL, and Embase databases in May 2020 and repeated in May 2021 (as there were delays completing this review due to the COVID-19 pandemic). Health science academic librarians provided guidance on the database searches. Three categories of concepts that were derived from the research question were used in the literature search. The first category related to oral and dental health, dentistry, and oral health professionals. The second category related to dietitians, nutrition services, dietetics, food, nutrition, and diet. The third category related to professional practices and behaviours. The MEDLINE search strategy is provided in Table 1.

Table 1. MEDLINE search strategy.

\begin{tabular}{|c|c|c|}
\hline $\begin{array}{l}\text { Concept Category \#1: Oral and } \\
\text { Dental Health, Dentistry, Oral } \\
\text { Health Professionals }\end{array}$ & $\begin{array}{l}\text { Concept Category \#2: Dietitians, } \\
\text { Nutrition Services, Dietetics, } \\
\text { Food, Nutrition, Diet }\end{array}$ & $\begin{array}{l}\text { Concept Category \#3: } \\
\text { Professional Practices and } \\
\text { Behaviours }\end{array}$ \\
\hline $\begin{array}{l}\text { Oral Health/OR exp periodontal } \\
\text { diseases/OR exp tooth } \\
\text { diseases/OR exp Dentition/OR } \\
\text { exp Odontogenesis/OR exp } \\
\text { dental auxiliaries/OR exp dental } \\
\text { staff/OR exp dentists/OR exp } \\
\text { faculty, dental/OR exp } \\
\text { dentistry/OR exp public health } \\
\text { dentistry/OR exp Dental } \\
\text { Facilities/OR exp Dental Health } \\
\text { Services/OR Dental Records/OR } \\
\text { exp societies, dental/OR } \\
\text { Licensure, Dental/OR Schools, } \\
\text { Dental/OR exp Education, } \\
\text { Dental/OR Insurance, Dental/OR } \\
\text { exp Economics, Dental/OR } \\
\text { dent*.ti,ab,kw. OR tooth.ti,ab,kw. } \\
\text { OR teeth.ti,ab,kw. }\end{array}$ & $\begin{array}{l}\text { exp “diet, food, and } \\
\text { nutrition" /OR exp } \\
\text { Carbohydrates/OR exp sugar } \\
\text { alcohols/OR drinking } \\
\text { behavior/OR exp feeding } \\
\text { behavior/OR exp Feeding } \\
\text { Methods/OR Cariogenic } \\
\text { Agents/OR Nutritionists/OR exp } \\
\text { Nutritional Sciences/OR exp } \\
\text { Dietary Services/OR exp } \\
\text { Nutrition Therapy/OR nutrition } \\
\text { assessment/OR exp Body } \\
\text { Weight/OR exp Nutrition } \\
\text { Disorders/OR diet*.ti,ab,kw. OR } \\
\text { sugar*.ti,ab,kw. OR } \\
\text { nutritio*.ti,ab,kw. }\end{array}$ & $\begin{array}{l}\text { "attitude of health } \\
\text { personnel" /OR attitude to } \\
\text { health/OR health knowledge, } \\
\text { attitudes, practice/OR Practice } \\
\text { Patterns, Dentists' /OR } \\
\text { professional-patient relations/OR } \\
\text { professional-family relations/OR } \\
\text { interprofessional relations/OR } \\
\text { interdisciplinary } \\
\text { communication/OR intersectoral } \\
\text { collaboration/OR Patient Care } \\
\text { Team/OR Professional Practice } \\
\text { Gaps/OR exp Professional } \\
\text { Practice/OR exp Professional } \\
\text { Role/OR practice*.ti,ab,kw. OR } \\
\text { interprofessional*.ti,ab,kw. OR } \\
\text { interdisciplin*.ti,ab,kw. OR } \\
\text { multidisciplin*.ti,ab,kw. OR } \\
\text { collaborat*.ti,ab,kw. OR } \\
\text { multi-disciplin*.ti,ab,kw. OR } \\
\text { inter-disciplin*.ti,ab,kw. OR } \\
\text { trans-disciplin*.ti,ab,kw. OR } \\
\text { transdisciplin*.ti,ab,kw. OR } \\
\text { cross-disciplin*.ti,ab,kw. OR } \\
\text { referral*.ti,ab,kw. }\end{array}$ \\
\hline
\end{tabular}

In addition to database searches, reference lists from all included articles were examined for additional articles. Moreover, the citations for relevant articles were searched in Google Scholar for any other papers that might have been missed. Relevant review articles in this area were also consulted to capture any additional articles $[25,29,30]$. Hand searches of journals likely to have articles in this area (Journal of Dental Hygiene, International Journal of Dental Hygiene, Community Dental Health, Canadian Journal of Dental Hygiene) were also conducted. All articles were imported into a reference management system and duplicates were removed.

Stage 3: Article Selection

Article inclusion and exclusion criteria are listed in Table 2. In order to be included, articles had to meet the following criteria: English language, published in year 2000 or later, conducted in a World Bank high-income country, reported information on the "realworld" practices of dietitians/nutritionists and/or oral health professionals (not including students) regarding nutrition care for oral health (and specifically conditions affecting the dentition and periodontium). Articles were included regardless of quality. Clinical trials were not included except for baseline information on current professional practices. The year 2000 was chosen to select articles that were relatively recent. World Bank high-income 
countries were chosen to provide articles that are most relevant to the Canadian context. Exclusion criteria included information on the practices of students (e.g., nutrition students, dental students, dental hygiene students), where results of dietitians/nutritionists and/or oral health professionals were combined with other professionals (e.g., nurses, physicians) and could not be isolated, information on professional commentary regarding treatment plans for case studies, and when information about nutrition care practices was combined with other dental prevention practices (and cannot be isolated) (e.g., dental preventative activities in general were assessed which could include nutrition interventions amongst other activities such as fluoride application). Studies that were conducted in Special Supplemental Nutrition Program for Women, Infant, and Children (WIC) personnel were included as well. WIC is a federally funded government program in the United States that is available for low-income pregnant women, postpartum breastfeeding and nonbreastfeeding women, and children less than 5 years of age [31]. This program provides healthy foods, nutrition education, and health care referrals. Of note, many WIC staff members are also dietitians. We also included studies that included information on practices related to oral health (e.g., tooth brushing instruction) in dietitians, nutritionists and/or WIC personnel.

Table 2. Inclusion and exclusion criteria.

\begin{tabular}{|c|c|}
\hline Inclusion Criteria & Exclusion Criteria \\
\hline $\begin{array}{l}\text { - } \\
\text { - } \\
\text { Peerticle published in year } 2000 \text { or later } \\
\text { - } \quad \text { Article written in English } \\
\text { - } \quad \text { Study conducted in humans } \\
\text { country } \\
\text { Article reported information on the real-world } \\
\text { nutrition care practices (e.g., diet advice, } \\
\text { nutrition counselling) (including barriers) of } \\
\text { dietitians/nutritionists/WIC personnel and/or } \\
\text { oral health professionals to optimize oral } \\
\text { health (and specifically the dentition and } \\
\text { periodontium). } \\
\quad \text { Studies describing the nutrition care } \\
\quad \text { practices of oral health professionals } \\
\quad \text { without reference to a specific oral } \\
\quad \text { health condition were included as they } \\
\quad \text { were assumed to be referring to oral } \\
\quad \text { health, specifically the } \\
\quad \text { dentition/periodontium. } \\
\text { Articles that reported practices related to oral } \\
\text { health (e.g., tooth brushing counselling) in } \\
\text { dietitians/nutritionists/WIC personnel } \\
\text { without reference to a specific oral health } \\
\text { condition were included as they were assumed } \\
\text { to be referring to oral health and specifically } \\
\text { dentition/periodontium. }\end{array}$ & $\begin{array}{l}\text { Letters to the editor, commentaries, conference } \\
\text { abstracts, thesis documents, grey literature, } \\
\text { review articles } \\
\text { Information about practices and/or barriers of } \\
\text { providing nutrition care reported by students } \\
\text { (e.g., nutrition students, dental students, dental } \\
\text { hygiene students) } \\
\text { Information about nutrition care practices for } \\
\text { dietitians/nutritionists/WIC personnel and/or } \\
\text { oral health professionals is combined with } \\
\text { other dental prevention activities (and cannot } \\
\text { be isolated) } \\
\text { Information about nutrition care practices of } \\
\text { dietitians/nutritionists/WIC personnel and/or } \\
\text { oral health professionals is combined with } \\
\text { another profession (e.g., nurses, physicians) } \\
\text { Information on nutrition care practices } \\
\text { provided by dietitians/nutritionists/WIC } \\
\text { personnel and/or oral health professionals } \\
\text { from the patient perspective } \\
\text { Information about practices regarding fluoride } \\
\text { supplements, sugar alcohols, herbal } \\
\text { - } \quad \text { Inpplements, homeopathy, and alcohol by oral } \\
\text { health professionals } \\
\text { Information about diabetes, obesity, } \\
\text { cardiovascular disease, hypertension } \\
\text { glucose screening/monitoring by oral health } \\
\text { professionals } \\
\text { dietitians/mutritionists/WIC personnel and/or } \\
\text { oral health professionals would treat } \\
\text { hypothetical patient case scenarios/studies } \\
\text { - }\end{array}$ \\
\hline
\end{tabular}

WIC: Special Supplemental Nutrition Program for Women, Infants, and Children.

Two individuals independently screened the titles and abstracts of all articles from the search conducted in May 2020 using the study inclusion and exclusion criteria with Rayyan [32]; if the abstracts did not provide enough information, the full text of the article was consulted. For the articles from the search conducted in May 2021, the articles were also screened by two individuals using the study inclusion and exclusion criteria. Cases of 
disagreement were reviewed and discussed by a third member of the research team until consensus was reached.

Stage 4: Charting the Data

The following information was charted from all eligible articles: author(s), year of publication, study location, study dates, study population, sample size, study methodology, oral health issue of focus, and key findings. Only information relevant to the inclusion criteria was extracted; for example, if a study included information about physicians and oral health professionals, only the information about oral health professionals was charted. The source of funding for the included studies was also captured. As with many scoping reviews, a quality assessment was not carried out.

Stage 5: Collating, Summarizing, and Reporting the Results

Following extraction of all data, the results were collapsed into tables to report information on sample size, type of professional studied, patient population and/or concern of focus, and information about the topics investigated in the article. This process was conducted by JRLL, and the content was verified by AGTV or JRdM by looking at the content of the table and cross-checking it with the article. The articles were sorted based on the type of professional studied, the types of outcomes reported, and the study methodology.

\section{Results}

In total, $n=70$ articles were included in the scoping review (Figure 1). Most articles describe studies that were conducted in one of the following four regions: United States $(n=23)$, United Kingdom $(n=17)$, Nordic countries (Norway, Finland, Iceland, Sweden, Denmark) $(n=12)$, and Australia $(n=7)$. However, there were also articles from Japan $(n=3)$, Germany $(n=2)$, Saudi Arabia $(n=2)$, Canada $(n=1)$, Hong Kong $(n=1)$, New Zealand $(n=1)$, and Taiwan $(n=1)$. In total, $n=32$ articles were published in 2010 or earlier and $n=38$ articles were published in 2011 or later. Almost half of the articles did not report any funding source $(n=32)$; articles reporting funding sources $(n=38$ articles) reported that their studies were funded by various sources including government/government agency ( $n=25$ articles), university/hospital $(n=6)$, professional association/organization $(n=3)$, and other sources (i.e., foundation, charity, company) $(n=10)$.

Most studies focused on oral health professionals; only six studies provided information on dietitians, nutritionists, and/or WIC personnel (many of whom are dietitians or nutritionists). Most articles did not focus specifically on diet and nutrition but rather had focuses including preventative dentistry, prevention and/or treatment of specific oral health conditions, infant oral health care/examinations, dental practice patterns, and public dental service use. Only $n=18$ articles referred to something that was obviously related to nutrition and/or diet in their title (e.g., diet, nutrition, sugar-sweetened beverage, dietitian, nutritionist, WIC). Most included articles were cross-sectional survey studies of professionals (sample size range: $n=9$ to $n=2294$ professionals); however, other study methods included chart reviews (sample size range: $n=285$ to $>10,000$ patients), observation studies (sample size: $n=3751$ patient visits in 120 general dental practices), and qualitative interviews and/or focus groups of professionals (sample size range: $n=10$ to 93). In addition, one study captured information on how different types of data compared to one another.

In this review, the articles were organized based on the type of professional studied, the methods used in the study (e.g., survey, qualitative interview), and types of care provided which encompassed either assessment practices (i.e., dietary assessment practices by oral health professionals; assessment practices regarding oral health and nutrition by dietitians, nutritionists, and/or WIC personnel) or intervention practices (e.g., diet counselling, diet advice by oral health professionals; intervention practices regarding oral health and nutrition by dietitians, nutritionists, and/or WIC personnel). Of note, two crosssectional survey studies included only a combined measure of assessment and intervention practices; these articles are included in both of those sections. 


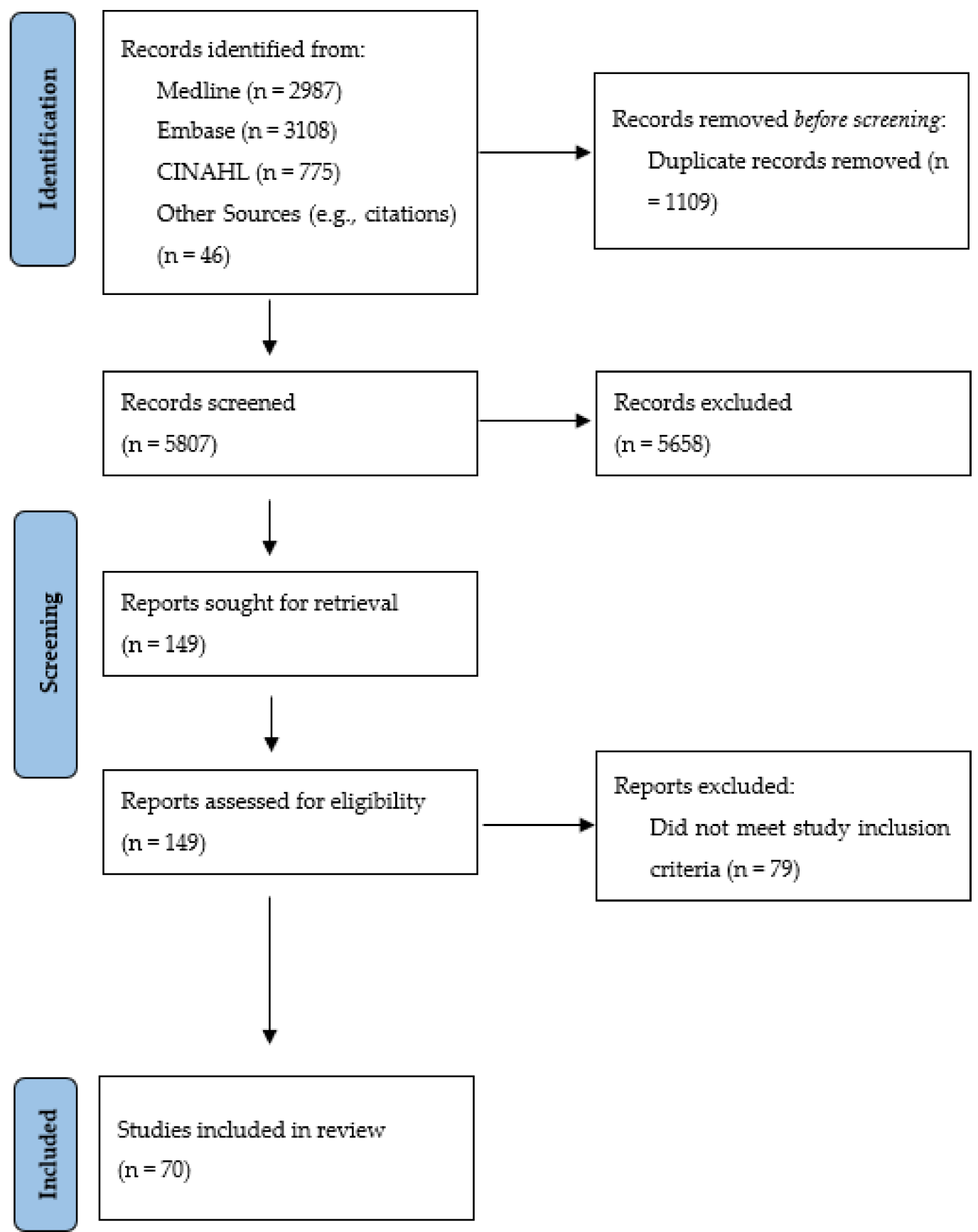

Figure 1. Search results.

\subsection{Assessment Practices}

\subsubsection{Oral Health Professionals}

Nineteen articles provided information on the dietary assessment practices of oral health professionals. These studies are described in Table 3. Overall, most of these articles were cross-sectional survey studies usually of dentists; however, other types of studies also captured this information, including chart reviews and a qualitative interview study. Overall, these studies captured information on various dietary assessment practices including general/unspecific assessment practices (e.g., dietary analysis), use of specific diet assessment tools (e.g., food records), and inquiries about specific patient behaviours or concerns (e.g., bottle use, cariogenic food consumption). In addition, two studies examined barriers regarding dietary assessment. A few of these studies examined whether there were 
differences in these outcomes by professional type, patient type, and various professional and practice factors.

Table 3. Assessment practice information reported in the included articles.

\begin{tabular}{|c|c|c|c|c|c|c|c|}
\hline $\begin{array}{l}\text { Study Authors, } \\
\text { Year, and } \\
\text { Country }\end{array}$ & $\begin{array}{l}\text { Sample } \\
\text { Size * }\end{array}$ & Professional Type & $\begin{array}{c}\text { Population } \\
\text { and/or Concern } \\
\text { of Focus }\end{array}$ & $\begin{array}{c}\text { General/Unspecific } \\
\text { Assessment } \\
\text { Practices (e.g., } \\
\text { Dietary Analysis) }\end{array}$ & $\begin{array}{c}\text { Use of Specific } \\
\text { Assessment Tools, } \\
\text { Strategies, or } \\
\text { Practices (e.g., } \\
\text { Food Records) }\end{array}$ & $\begin{array}{c}\text { Inquiries about } \\
\text { Specific Patient } \\
\text { Behaviours or } \\
\text { Concerns (e.g., } \\
\text { Bottle Use, } \\
\text { Cariogenic Food } \\
\text { Consumption) }\end{array}$ & $\begin{array}{c}\text { Barriers (or } \\
\text { Reasons for } \\
\text { Lack of Use) } \\
\text { Regarding } \\
\text { Assessment } \\
\text { Practices }\end{array}$ \\
\hline \multicolumn{8}{|c|}{ SURVEY STUDIES } \\
\hline \multicolumn{8}{|c|}{ Oral Health Professionals } \\
\hline $\begin{array}{l}\text { Roshan et al., } \\
2003 \text { [33]; UK }\end{array}$ & 687 & $\begin{array}{c}\text { general dental } \\
\text { practitioners; } \\
\text { community dental } \\
\text { officers }\end{array}$ & children & $(\mathrm{X})^{\text {Practice } / \text { Prof }}$ & & & \\
\hline $\begin{array}{c}\text { Hawkins and } \\
\text { Locker, } 2005 \text { [34]; } \\
\text { Canada }\end{array}$ & 672 & general dentists & older adults & & $x$ & $X^{\text {Practice/Prof }}$ & \\
\hline $\begin{array}{c}\text { Sajnani- } \\
\text { Oommen et al., } \\
2006 \text { [35]; USA }\end{array}$ & 180 & pediatric dentists & children & & $x$ & & \\
\hline $\begin{array}{l}\text { Bubna et al., } \\
2012 \text { [36]; USA }\end{array}$ & 554 & pediatric dentists & infants & $(\mathrm{X})$ & & & \\
\hline $\begin{array}{c}\text { Clovis et al., } 2012 \\
\text { [37]; USA }\end{array}$ & 540 & dental hygienists & $\begin{array}{l}\text { children; dental } \\
\text { caries }\end{array}$ & & & $X^{\text {Practice/Prof }}$ & \\
\hline $\begin{array}{c}\text { Mulic et al., } 2012 \\
\text { [38]; Norway }\end{array}$ & 705 & $\begin{array}{l}\text { public dental } \\
\text { health service } \\
\text { dentists }\end{array}$ & $\begin{array}{l}\text { adults; dental } \\
\text { erosive wear }\end{array}$ & $x$ & $x$ & & \\
\hline $\begin{array}{l}\text { Garton and Ford, } \\
2013 \text { [39]; } \\
\text { Australia }\end{array}$ & 638 & $\begin{array}{l}\text { dentists (including } \\
\text { specialists) }\end{array}$ & root caries & $x$ & & & $X^{\text {Practice/Prof }}$ \\
\hline $\begin{array}{l}\text { Sim et al., } \\
2014 \text { [40]; USA }\end{array}$ & 86 & pediatric dentists & $\begin{array}{c}\text { infants and } \\
\text { toddlers; dental } \\
\text { caries }\end{array}$ & & & $x$ & \\
\hline $\begin{array}{l}\text { Yusuf et al., } \\
2016 \text { [41]; UK }\end{array}$ & 164 & $\begin{array}{c}\text { National Health } \\
\text { Service general } \\
\text { dental practitioners }\end{array}$ & & $X^{\text {Practice/Prof }}$ & & & \\
\hline $\begin{array}{l}\text { Widström et al., } \\
2016 \text { [42]; } \\
\text { Norway }\end{array}$ & $\begin{array}{l}215 \text { dentists; } \\
166 \text { dental } \\
\text { hygienists }\end{array}$ & $\begin{array}{l}\text { dentists; dental } \\
\text { hygienists in public } \\
\text { dental service }\end{array}$ & $\begin{array}{l}\text { public dental } \\
\text { service } \\
\text { clients-children } \\
\text { and adults }\end{array}$ & $X^{\text {Professional Type; Patient }}$ & & & \\
\hline $\begin{array}{l}\text { Arheiam et al., } \\
2016 \text { [43]; UK }\end{array}$ & 250 & $\begin{array}{l}\text { general dental } \\
\text { practitioners }\end{array}$ & children; adults & & $X^{\text {Practice/Prof; Patient }}$ & & $X^{\text {Patient }}$ \\
\hline $\begin{array}{c}\text { Halawany et al., } \\
2017 \text { [44]; Saudi } \\
\text { Arabia }\end{array}$ & 108 & pediatric dentists & $\begin{array}{c}\text { children; dental } \\
\text { caries }\end{array}$ & $x$ & & & \\
\hline $\begin{array}{c}\text { Dima et al., } \\
2018 \text { [45]; Taiwan }\end{array}$ & 196 & $\begin{array}{l}\text { general dentists; } \\
\text { pediatric dentists }\end{array}$ & $\begin{array}{l}\text { children; early } \\
\text { childhood caries }\end{array}$ & & & $X^{\text {Professional Type }}$ & \\
\hline $\begin{array}{c}\text { Mulic et al., } \\
2018 \text { [46]; Iceland }\end{array}$ & 153 & dentists & $\begin{array}{l}\text { dental erosive } \\
\text { wear }\end{array}$ & $x$ & $x$ & & \\
\hline $\begin{array}{c}\text { Kangasmaa et al., } \\
2021 \text { [47]; } \\
\text { Finland }\end{array}$ & 814 & $\begin{array}{l}\text { general dentists; } \\
\text { dental specialists }\end{array}$ & $\begin{array}{l}\text { erosive tooth } \\
\text { wear }\end{array}$ & $\mathrm{X}^{\text {Practice/Prof; Professional }}$ & & & \\
\hline $\begin{array}{l}\text { Mortensen et al., } \\
2021 \text { [48]; } \\
\text { Denmark }\end{array}$ & 419 & dentists & $\begin{array}{l}\text { erosive tooth } \\
\text { wear }\end{array}$ & $x$ & $x$ & & \\
\hline \multicolumn{8}{|c|}{ Dietitians/Nutritionists } \\
\hline $\begin{array}{l}\text { Fuller et al., } \\
2014 \text { [49]; USA }\end{array}$ & 159 & $\begin{array}{l}\text { WIC program } \\
\text { personnel }\end{array}$ & $\begin{array}{c}\text { WIC clients; } \\
\text { early childhood } \\
\text { caries }\end{array}$ & $X^{\text {Practice/Prof }}$ & & & \\
\hline $\begin{array}{l}\text { Gold and Tomar, } \\
2016 \text { [50]; USA }\end{array}$ & 9 & WIC nutritionists & WIC clients & $x$ & $x$ & $x$ & \\
\hline $\begin{array}{l}\text { Fernandez et al., } \\
2017 \text { [51]; USA }\end{array}$ & 36 & $\begin{array}{l}\text { dietitians who } \\
\text { completed a } \\
\text { pediatric dentistry } \\
\text { internship rotation }\end{array}$ & & $X^{\text {Patient }}$ & & & \\
\hline
\end{tabular}


Table 3. Cont.

\begin{tabular}{|c|c|c|c|c|c|c|c|}
\hline $\begin{array}{l}\text { Study Authors, } \\
\text { Year, and } \\
\text { Country }\end{array}$ & $\begin{array}{c}\text { Sample } \\
\text { Size }^{*}\end{array}$ & Professional Type & $\begin{array}{c}\text { Population } \\
\text { and/or Concern } \\
\text { of Focus }\end{array}$ & $\begin{array}{c}\text { General/Unspecific } \\
\text { Assessment } \\
\text { Practices (e.g., } \\
\text { Dietary Analysis) }\end{array}$ & $\begin{array}{l}\text { Use of Specific } \\
\text { Assessment Tools, } \\
\text { Strategies, or } \\
\text { Practices (e.g.; } \\
\text { Food Records) }\end{array}$ & $\begin{array}{c}\text { Inquiries about } \\
\text { Specific Patient } \\
\text { Behaviours or } \\
\text { Concerns (e.g., } \\
\text { Bottle Use, } \\
\text { Cariogenic Food } \\
\text { Consumption) }\end{array}$ & $\begin{array}{c}\text { Barriers (or } \\
\text { Reasons for } \\
\text { Lack of Use) } \\
\text { Regarding } \\
\text { Assessment } \\
\text { Practices }\end{array}$ \\
\hline \multicolumn{8}{|c|}{ CHART REVIEW STUDIES } \\
\hline \multicolumn{8}{|c|}{ Oral Health Professionals } \\
\hline $\begin{array}{l}\text { Sarmadi et al., } \\
\text { 2009 [52]; } \\
\text { Sweden }\end{array}$ & 432 & $\begin{array}{l}\text { public dental } \\
\text { service (dentists } \\
\text { and dental } \\
\text { hygienists) }\end{array}$ & $\begin{array}{l}\text { children 6-19 } \\
\text { years at high risk } \\
\text { of developing } \\
\text { dental caries }\end{array}$ & $X^{\text {Patient }}$ & & & \\
\hline $\begin{array}{l}\text { O'Toole et al., } \\
2018 \text { [53]; UK }\end{array}$ & 285 & dentists & $\begin{array}{l}\text { adults; tooth } \\
\text { wear }\end{array}$ & $X^{\text {Practice/Prof }}$ & & & \\
\hline \multicolumn{8}{|c|}{ QUALITATIVE INTERVIEW STUDIES } \\
\hline \multicolumn{8}{|c|}{ Oral Health Professionals } \\
\hline $\begin{array}{l}\text { Threlfall et al., } \\
2007 \text { [54]; UK }\end{array}$ & 93 & $\begin{array}{l}\text { general dental } \\
\text { practitioners }\end{array}$ & $\begin{array}{l}\text { children; dental } \\
\text { caries }\end{array}$ & $X^{\text {Patient }}$ & $x$ & & \\
\hline
\end{tabular}

* Sample size for survey studies and qualitative interview studies refers to number of professionals included; sample size for chart review studies refers to the number of patients included. WIC: Special Supplemental Nutrition Program for Women, Infants, and Children. $(X)=$ study measure included both assessment and intervention practices combined together (e.g., analyzed diets and gave dietary advice). Patient $=$ examine differences in assessment practices in different types of patients (e.g., children vs. adults, severe dental caries vs. not). Professional Type $=$ examine differences in assessment practices in different types of professionals (e.g., general dentists vs. pediatric dentists, dentists vs. dental hygienists). Practice/Prof $=$ examine differences in assessment practices for different practice characteristics (e.g., public vs. private, rural practice vs. urban practice) and/or health professional characteristics (e.g., demographics, education, attitudes).

\section{General/Unspecific Dietary Assessment Practices}

Thirteen articles reported information on general/unspecific dietary assessment practices (e.g., dietary analysis, dietary history, assessment of dietary habits, asking about dietary behaviour, diet history review and analysis) of oral health professionals (cross-sectional survey studies $(n=10)[33,36,38,39,41,42,44,46-48]$; chart review studies $(n=2)$ [52,53], qualitative interview study $(n=1)$ [54]). Most of the articles reported information regarding these practices in dentists.

Within the cross-sectional survey studies, various self-reported measures were used to capture information on general/unspecific dietary assessment practices. One self-reported measure used in some of these studies was the proportion of respondents who provide this type of service in the population of interest [36,44]. These studies were conducted in pediatric dentists and found that this activity was common in the population of interest (e.g., $>90 \%$ of pediatric dentists who performed infant oral health evaluations reported this practice [36]; $70.6 \%$ of pediatric dentists reported doing a diet history review and analysis regarding dental caries prevention [44]). Several cross-sectional survey studies also reported self-reported information on frequency of providing some type of general/unspecific dietary assessment practice $[33,38,39,42,46-48]$. Overall, these studies were conducted regarding these practices when assisting patients with specific dental conditions (e.g., root caries [39], erosive tooth wear [38,46-48]) and in children [33,42] and adult [42] patient groups. In articles that focused on specific dental conditions, the percentage of respondents who self-reported always, often, and/or usually providing some type of general/unspecific dietary assessment practice ranged from $45 \%$ to $81 \%$, and the percentage of respondents who never or seldom performed this practice ranged from $1 \%$ to $25 \%[38,39,46-48]$. In studies focusing on children and/or adults, the percentage of respondents who self-reported never performing this practice ranged from $2 \%$ to $6.4 \%$ [33,42]. The chart review studies that assessed general/unspecific dietary assessment practices found results that are slightly different compared to results found in the survey studies. These studies, which included one focusing on pediatric patients at high risk for developing dental caries in a public dental service [52] and another focusing on tooth wear in adults in general dental 
practice [53], found that $<25 \%$ of patients had this type of assessment documented in their dental records.

The studies of Widström et al. [42] and Kangasmaa et al. [47] were the only studies that compared general/unspecific dietary assessment practices amongst different types of oral health professionals. Widström et al. [42] found in their survey study that dental hygienists were significantly more likely to assess dietary habits in all or most of their patients vs. dentists in both children and adult patients. Kangasmaa et al. [47] found regarding erosive tooth wear that there was no difference in the frequency of assessing a patient's dietary history between general dentists and different types of dental specialists. In addition, four studies $[33,41,47,53]$ examined professional and practice factors that impact the frequency with which dentists provide general/unspecific dietary assessment services for their patients. Overall, these studies found that dentists who were significantly more likely to practice this activity were less experienced (vs. more experienced) [53], work as a community dental officer (vs. general dental practitioner) [33], and have positive attitudes regarding prevention [41].

Three studies examined whether patient-related factors were associated with whether oral health professionals perform general/unspecific dietary assessment activities [42,52,54]. Widström et al. [42] found in their survey study that dentists and dental hygienists were more likely to perform an assessment of dietary habits in children compared to adults (e.g., $\%$ of dentists and dental hygienists who perform an assessment of dietary habits in all or most of their child patients: $18.9 ; \%$ of dentists and dental hygienists who perform an assessment of dietary habits in all or most of their adult patients: 8.3). Threlfall et al. [54] found in their qualitative interview study of general dental practitioners that they were more likely to ask questions about a child's diet if the child had dental caries.

Garton and Ford [39] investigated barriers reported by dentists regarding performing dietary analysis for root caries. They found that $43.3 \%$ of respondents reported barriers to providing dietary analysis. Time was the most common barrier ( $33.9 \%$ of respondents); however, other barriers encountered by $<10 \%$ of respondents included cost, lack of usefulness, lack of authority to order, and dietary analysis not being evidence-based. In addition, these authors found statistically significantly more dentists working in the public sector vs. the private sector reported the barrier of lack of authority to order (public: $8.7 \%$ vs. private: $1.7 \%)$.

\section{Use of Specific Dietary Assessment Tools}

Six studies provide information on self-reported use of specific dietary assessment tools (e.g., diet diary) by oral health professionals (cross-sectional survey studies $(n=5)[35,38,43,46,48]$; qualitative interview study $(n=1)$ [54]); of note, all of these studies were conducted in dentists. Overall, the survey studies found that less than $50 \%$ of dentists self-reported using some type of diet diary with their patients (e.g., $9 \%$ of pediatric dentists [35]; $28 \%$ of general dental practitioners [43]; $12-31 \%$ of dentists when referring to care of patients with erosive tooth wear $[38,46,48])$. These studies also found that less structured diet assessment approaches (e.g., oral interviews, asking patients to recall usual activities for a specified period) tend to be more commonly used by dentists compared to diet diaries [38,43,46,48].

Arheiam et al. [43] studied the use of diet diaries in UK general dental practitioners, including reasons for using diet diaries, factors that are considered when deciding to use these tools, routines when using diet diaries, and reasons for not using diet diaries. Of note, they found that diet diaries were more commonly used in children vs. adults, and the top reasons for lack of use of diet diaries were inadequate remuneration by the National Health Service (NHS), lack of usefulness, lack of knowledge, and poor compliance. The authors also found statistically significant predictors of diet diary use in a multivariate model were years of service, percentage of NHS patients in practice, and percentage of case-mix children in practice. The authors also reported the median time required to complete a diet diary analysis was $10 \mathrm{~min}$ (range: 1-23 $\mathrm{min}$ ) and that patients were asked to keep a 
diary for a median of 3 days (range: 1-7 days) [43]. Lastly, a qualitative interview study by Threlfall et al. [54] found that a few general dental practitioners had attempted to use diet sheets in children, but reported little success.

Inquiries about Specific Patient Behaviours or Concerns Related to Diet

In total, four cross-sectional survey studies report information on inquiries by oral health professionals about specific patient behaviours or concerns related to diet $[34,37,40,45]$; three of these studies were conducted in dentists $[34,40,45]$ and one was conducted in dental hygienists [37]. Three of these studies captured self-reported information on asking about specific behaviours related to dental caries in children (e.g., between-meal exposure to food that causes dental caries, bottle use, juice consumption) [37,40,45], and one study focused on older adults [34].

Overall, the studies that captured information on inquires about specific behaviours in children related to diet and dental caries found that this practice is relatively common $[37,40,45]$. For example, Clovis et al. [37] found that among dental hygienists who routinely assess their child/youth patients for risk factors related to dental caries $(88.7 \%$ of respondents), $64.9 \%$ self-reported asking about between-meal exposure to cavity-producing foods. In addition, Sim et al. [40] found that the frequency of asking about different feeding practices (including bottle feeding and juice consumption) in infants and toddlers can vary depending on the practice (e.g., $77 \%$ of respondents reported asking about bottle contents all of the time vs. $27 \%$ of respondents reported asking about age of first juice consumption all of the time). One study captured differences in these types of practices between different types of oral health professionals. Dima et al. [45] found that a significantly higher percentage of pediatric dentists self-report asking about bottle use often or very often compared to general dentists $(94.9 \%$ vs. $67.2 \%)$.

In general dentists, Hawkins and Locker [34] found that asking about different types of behaviours relevant to eating in older adults varied depending on the behaviour (e.g., $55 \%$ of respondents usually asked about prevention from eating desired foods because of chewing problems vs. $15 \%$ of respondents usually asked about avoiding eating with other people because of chewing problems). These authors [34] also found that numerous practice and dentist demographic characteristics were significantly related to inquiring about various behaviours relevant to eating in older adults in bivariate (and for some variables multivariate) analyses including dentist involvement in taking patient history, selfrated ability to treat older adults who reside in institutional settings, estimated percentage of patients $65+$ years of age, continuing education in geriatric dentistry in the last year, time taken to obtain a patient history, dentist age, population size of primary practice location, and dental school experience in geriatric outreach care.

\subsubsection{Dietitians and Nutritionists}

Three cross-sectional survey studies captured self-reported information about assessment practices of dietitians and/or nutritionists (including WIC personnel) related to nutrition and oral health or oral health only [49-51]; these studies are also described in Table 3. Fuller et al. [49] found that less than $50 \%$ of surveyed WIC personnel assessed children for visual evidence of dental caries; they further found that respondents $\geq 40$ years of age were significantly more likely to do this practice compared to respondents 18-39 years of age (53\% vs. $28 \%$ ). Gold and Tomar [50] found in a small study of WIC nutritionists that $33 \%$ of respondents frequently asked about women's and caregivers' dental health and no respondents reported frequently examining the teeth of children for dental caries. They also found that $100 \%$ of respondents frequently asked about whether the child brought a bottle to bed. In addition, Fernandez et al. [51] found in dietitians who had completed an elective pediatric dentistry rotation during their dietetic internship training that $28 \%$ always and $31 \%$ never collect information on an adult's oral health history and $24 \%$ always and $38 \%$ never collect information on a child's oral health history. 


\subsection{Intervention Practices}

\subsubsection{Oral Health Professionals}

Nutrition intervention practices (e.g., diet counselling, nutrition counselling, dietary advice, dietary instruction, providing information on diet, nutrition advice) in oral health professionals were investigated in $n=48$ studies (presented in $n=53$ articles); these studies are described in Table 4. Overall, most articles reported on cross-sectional survey studies ( $n=36$ studies presented in $n=39$ articles). In addition, there were $n=8$ chart review studies (one of which had professionals keep detailed documents of encounters over a 2-week period), $n=1$ observation study that also included a survey and chart review study (presented in $n=2$ articles), and $n=3$ qualitative interview/focus group studies (presented in $n=4$ articles) that were included. In general, most of the studies provided information on general/unspecified nutrition intervention practices (e.g., nutrition counselling, diet advice); however, there were also studies that discussed types of resources/strategies used, information provided to patients, and barriers regarding intervention practices.

Table 4. Intervention practice information reported in the included articles.

\begin{tabular}{|c|c|c|c|c|c|c|c|c|}
\hline $\begin{array}{c}\text { Study } \\
\text { Authors, Year, } \\
\text { and Country }\end{array}$ & Sample Size * & $\begin{array}{c}\text { Professional } \\
\text { Type }\end{array}$ & $\begin{array}{l}\text { Population } \\
\text { and/or } \\
\text { Concern of } \\
\text { Focus }\end{array}$ & $\begin{array}{c}\text { General/ } \\
\text { Unspecific } \\
\text { Intervention } \\
\text { Practices (e.g., } \\
\text { Nutrition } \\
\text { Counselling, } \\
\text { Diet Advice) }\end{array}$ & $\begin{array}{c}\text { Types of } \\
\text { Resources/ } \\
\text { Strategies } \\
\text { Used }\end{array}$ & $\begin{array}{l}\text { Information } \\
\text { Provided to } \\
\text { Patients }\end{array}$ & $\begin{array}{c}\text { Barriers } \\
\text { Regarding } \\
\text { Intervention } \\
\text { Practices }\end{array}$ & $\begin{array}{c}\text { Referrals/ } \\
\text { Collaboration } \\
\text { between } \\
\text { Dentistry and } \\
\text { Nutri- } \\
\text { tion/Dietetics }\end{array}$ \\
\hline \multicolumn{9}{|c|}{ SURVEY STUDIES } \\
\hline \multicolumn{9}{|c|}{ Oral Health Professionals } \\
\hline $\begin{array}{l}\text { Chisick et al., } \\
2000 \text { [55]; USA }\end{array}$ & 606 & $\begin{array}{l}\text { full-time } \\
\text { military or } \\
\text { civilian } \\
\text { dentists in the } \\
\text { Army Dental } \\
\text { Care System }\end{array}$ & & $x$ & $x$ & $x$ & & $x$ \\
\hline $\begin{array}{l}\text { Anderson } \\
\text { et al., } 2002 \text { [56]; } \\
\text { Wales }\end{array}$ & 568 & $\begin{array}{l}\text { dentists; } \\
\text { dental } \\
\text { hygienists; } \\
\text { dental } \\
\text { therapists }\end{array}$ & & & & $x$ & & \\
\hline $\begin{array}{l}\text { Roshan et al., } \\
2003 \text { [33]; UK }\end{array}$ & 687 & $\begin{array}{l}\text { general dental } \\
\text { practitioners; } \\
\text { community } \\
\text { dental officers }\end{array}$ & children & $(\mathrm{X})^{\text {Practice } / \text { Prof }}$ & & & & \\
\hline $\begin{array}{c}\text { Dugmore and } \\
\text { Rock, } \\
2003 \text { [57]; UK }\end{array}$ & 227 & $\begin{array}{l}\text { general and } \\
\text { community } \\
\text { dental } \\
\text { practitioners }\end{array}$ & $\begin{array}{l}\text { children; tooth } \\
\text { erosion }\end{array}$ & $X^{\text {Patient }}$ & & $X^{\text {Patient }}$ & & \\
\hline $\begin{array}{c}\text { Freeman et al., } \\
2005 \text { [58]; } \\
\text { Northern } \\
\text { Ireland }\end{array}$ & 128 practices & $\begin{array}{c}\text { general dental } \\
\text { practices }\end{array}$ & dental caries & $x$ & & & & \\
\hline $\begin{array}{l}\text { Wang, } \\
2005 \text { [59]; } \\
\text { Norway }\end{array}$ & $\begin{array}{c}199 \text { (1995); } 210 \\
\text { (2004) }\end{array}$ & $\begin{array}{c}\text { dental } \\
\text { hygienists } \\
\text { from public } \\
\text { dental service }\end{array}$ & $\begin{array}{c}\text { children; } \\
\text { dental caries }\end{array}$ & $X^{\text {Patient }}$ & & & & \\
\hline $\begin{array}{l}\text { Huang et al., } \\
2006 \text { [60]; USA }\end{array}$ & 111 & orthodontists & $\begin{array}{c}\text { children; } \\
\text { dental caries }\end{array}$ & $X^{\text {Practice/Prof }}$ & $x$ & $x$ & $x$ & $x$ \\
\hline $\begin{array}{c}\text { Sajnani- } \\
\text { Oommen et al., } \\
2006 \text { [35]; USA }\end{array}$ & 180 & $\begin{array}{l}\text { pediatric } \\
\text { dentists }\end{array}$ & children & $X^{\text {Practice/Prof }}$ & & $x$ & & $x$ \\
\hline $\begin{array}{c}\text { Dyer and } \\
\text { Robinson, } \\
2006 \text { [61]; UK }\end{array}$ & 166 & $\begin{array}{l}\text { principal } \\
\text { dentists }\end{array}$ & & $x$ & & & $X^{\text {Professional Type }}$ & \\
\hline $\begin{array}{l}\text { Trueblood } \\
\text { et al., } 2008 \text { [62]; } \\
\text { USA }\end{array}$ & 127 & $\begin{array}{l}\text { pediatric } \\
\text { dentists }\end{array}$ & $\begin{array}{c}\text { children; } \\
\text { dental caries }\end{array}$ & $x$ & & & & \\
\hline $\begin{array}{l}\text { Brickhouse } \\
\text { et al., } 2008 \text { [63]; } \\
\text { USA }\end{array}$ & $\sim 221$ & $\begin{array}{l}\text { general } \\
\text { dentists; } \\
\text { pediatric } \\
\text { dentists }\end{array}$ & infants & $X^{\text {Professional Type }}$ & & $X^{\text {Professional Type }}$ & & \\
\hline
\end{tabular}


Table 4. Cont.

\begin{tabular}{|c|c|c|c|c|c|c|c|c|}
\hline $\begin{array}{c}\text { Study } \\
\text { Authors, Year, } \\
\text { and Country }\end{array}$ & Sample Size * & $\begin{array}{c}\text { Professional } \\
\text { Type }\end{array}$ & $\begin{array}{l}\text { Population } \\
\text { and/or } \\
\text { Concern of } \\
\text { Focus }\end{array}$ & $\begin{array}{c}\text { General/ } \\
\text { Unspecific } \\
\text { Intervention } \\
\text { Practices (e.g., } \\
\text { Nutrition } \\
\text { Counselling, } \\
\text { Diet Advice) }\end{array}$ & $\begin{array}{l}\text { Types of } \\
\text { Resources/ } \\
\text { Strategies } \\
\text { Used }\end{array}$ & $\begin{array}{l}\text { Information } \\
\text { Provided to } \\
\text { Patients }\end{array}$ & $\begin{array}{c}\text { Barriers } \\
\text { Regarding } \\
\text { Intervention } \\
\text { Practices }\end{array}$ & $\begin{array}{c}\text { Referrals/ } \\
\text { Collaboration } \\
\text { between } \\
\text { Dentistry and } \\
\text { Nutri- } \\
\text { tion/Dietetics }\end{array}$ \\
\hline \multicolumn{9}{|c|}{ SURVEY STUDIES } \\
\hline \multicolumn{9}{|c|}{ Oral Health Professionals } \\
\hline $\begin{array}{c}\text { Kelly and } \\
\text { Moynihan, } \\
2008 \text { [64]; UK }\end{array}$ & 879 & $\begin{array}{c}\text { dentists; } \\
\text { dental } \\
\text { hygienists; } \\
\text { other } \\
\text { occupations or } \\
\text { specialties }\end{array}$ & $\begin{array}{l}\text { periodontal } \\
\text { disease }\end{array}$ & $x$ & & $x$ & $x$ & \\
\hline $\begin{array}{l}\text { Csikar et al., } \\
2009 \text { [65]; UK }\end{array}$ & 386 & $\begin{array}{c}\text { dental } \\
\text { practitioners }\end{array}$ & & $X^{\text {Practice/Prof }}$ & & & & \\
\hline $\begin{array}{l}\text { Satur et al., } \\
2009 \text { [66]; } \\
\text { Australia }\end{array}$ & 59 & $\begin{array}{l}\text { dental } \\
\text { therapists }\end{array}$ & & $X^{\text {Practice/Prof }}$ & & & & \\
\hline $\begin{array}{c}\text { Tseveenjav } \\
\text { et al., } 2009 \text { [67]; } \\
\text { Finland and } \\
\text { Norway }\end{array}$ & 682 & $\begin{array}{c}\text { dental } \\
\text { hygienists }\end{array}$ & & $X^{\text {Practice/Prof }}$ & & & & \\
\hline $\begin{array}{l}\text { Malcheff et al., } \\
2009 \text { [68]; USA }\end{array}$ & 2157 & $\begin{array}{l}\text { pediatric } \\
\text { dentists }\end{array}$ & infants & $x$ & & & & \\
\hline $\begin{array}{l}\text { Manski and } \\
\text { Parker, } \\
2010 \text { [69]; USA }\end{array}$ & 308 & $\begin{array}{c}\text { dental } \\
\text { hygienists }\end{array}$ & $\begin{array}{l}\text { children; early } \\
\text { childhood } \\
\text { caries }\end{array}$ & $X^{\text {Practice/Prof }}$ & & & & \\
\hline $\begin{array}{c}\text { Salama and } \\
\text { Kebriaei, } \\
2010 \text { [70]; USA }\end{array}$ & 371 & $\begin{array}{l}\text { general } \\
\text { dentists }\end{array}$ & infants & $x$ & & & & \\
\hline $\begin{array}{l}\text { Ananaba et al., } \\
2010 \text { [71]; USA }\end{array}$ & 2294 & $\begin{array}{l}\text { general } \\
\text { dentists; } \\
\text { pediatric } \\
\text { dentists }\end{array}$ & infants & $\begin{array}{c}X_{\text {Professional Type; }}^{\text {Practice/Prof }} \\
\text { Prof }\end{array}$ & & & & \\
\hline $\begin{array}{c}\text { Cunha-Cruz } \\
\text { et al., } 2010 \text { [72]; } \\
\text { USA }\end{array}$ & 209 & dentists & $\begin{array}{l}\text { dentin hyper- } \\
\text { sensitivity }\end{array}$ & $x$ & & & & \\
\hline $\begin{array}{l}\text { Bubna et al., } \\
2012 \text { [36]; USA }\end{array}$ & 554 & $\begin{array}{l}\text { pediatric } \\
\text { dentists }\end{array}$ & infants & $(\mathrm{X})$ & & & & \\
\hline $\begin{array}{c}\text { Lee et al., } \\
2012 \text { [73]; USA }\end{array}$ & 1779 & $\begin{array}{l}\text { pediatric } \\
\text { dentists }\end{array}$ & $\begin{array}{c}\text { children; } \\
\text { dental caries }\end{array}$ & $X^{\text {Practice/Prof }}$ & & & & \\
\hline $\begin{array}{c}\text { Kakudate } \\
\text { et al., } 2012 \text { [74]; } \\
\text { Yokoyama } \\
\text { et al., } 2013 \text { [75]; } \\
\text { Yokoyama } \\
\text { et al., } 2013 \text { [76]; } \\
\text { Japan }\end{array}$ & 189 & dentists & & $X^{\text {Practice/Prof }}$ & & & & \\
\hline $\begin{array}{c}\text { Hussein et al., } \\
2013 \text { [77]; } \\
\text { Germany }\end{array}$ & 640 & dentists & & $X^{\text {Practice/Prof }}$ & & & & \\
\hline $\begin{array}{c}\text { Sim et al., } \\
2014 \text { [40]; USA }\end{array}$ & 86 & $\begin{array}{l}\text { pediatric } \\
\text { dentists }\end{array}$ & $\begin{array}{l}\text { infants and } \\
\text { toddlers; } \\
\text { dental caries }\end{array}$ & $X^{\text {Practice/Prof }}$ & & & $x$ & \\
\hline $\begin{array}{l}\text { Gnich et al., } \\
2014 \text { [78]; } \\
\text { Scotland }\end{array}$ & 174 & dental nurses & children & $X^{\text {Patient; Practice/Prof }}$ & & & & \\
\hline $\begin{array}{c}\text { Yusuf et al., } \\
2015 \text { [79]; } \\
\text { Yusuf et al., } \\
2016 \text { [41]; UK }\end{array}$ & 164 & $\begin{array}{c}\text { National } \\
\text { Health Service } \\
\text { general dental } \\
\text { practitioners }\end{array}$ & & $X^{\text {Practice/Prof }}$ & & & & \\
\hline $\begin{array}{l}\text { Arheiam et al., } \\
2016 \text { [43]; UK }\end{array}$ & 250 & $\begin{array}{c}\text { general dental } \\
\text { practitioners }\end{array}$ & & $x$ & $x$ & & & \\
\hline $\begin{array}{c}\text { Hayes et al., } \\
2016 \text { [80]; } \\
\text { Australia }\end{array}$ & 426 & $\begin{array}{l}\text { dental } \\
\text { hygienists; } \\
\text { oral health } \\
\text { therapists }\end{array}$ & & & & & $x$ & \\
\hline
\end{tabular}


Table 4. Cont.

\begin{tabular}{|c|c|c|c|c|c|c|c|c|}
\hline $\begin{array}{c}\text { Study } \\
\text { Authors, Year, } \\
\text { and Country }\end{array}$ & Sample Size * & $\begin{array}{l}\text { Professional } \\
\text { Type }\end{array}$ & $\begin{array}{l}\text { Population } \\
\text { and/or } \\
\text { Concern of } \\
\text { Focus }\end{array}$ & $\begin{array}{c}\text { General/ } \\
\text { Unspecific } \\
\text { Intervention } \\
\text { Practices (e.g., } \\
\text { Nutrition } \\
\text { Counselling, } \\
\text { Diet Advice) }\end{array}$ & $\begin{array}{c}\text { Types of } \\
\text { Resources/ } \\
\text { Strategies } \\
\text { Used }\end{array}$ & $\begin{array}{l}\text { Information } \\
\text { Provided to } \\
\text { Patients }\end{array}$ & $\begin{array}{c}\text { Barriers } \\
\text { Regarding } \\
\text { Intervention } \\
\text { Practices }\end{array}$ & $\begin{array}{c}\text { Referrals/ } \\
\text { Collaboration } \\
\text { between } \\
\text { Dentistry and } \\
\text { Nutri- } \\
\text { tion/Dietetics }\end{array}$ \\
\hline \multicolumn{9}{|c|}{ SURVEY STUDIES } \\
\hline \multicolumn{9}{|c|}{ Oral Health Professionals } \\
\hline $\begin{array}{c}\text { Baatsch et al., } \\
2017 \text { [81]; } \\
\text { Germany }\end{array}$ & 250 & dentists & & & & & & $X^{\text {Practice/Prof }}$ \\
\hline $\begin{array}{l}\text { Hayes et al., } \\
2017 \text { [82]; } \\
\text { Australia }\end{array}$ & 41 & $\begin{array}{l}\text { dentists; } \\
\text { dental } \\
\text { hygienists; } \\
\text { oral health } \\
\text { therapists }\end{array}$ & & $X^{\text {Professional Type }}$ & & & $X^{\text {Professional Type }}$ & \\
\hline $\begin{array}{l}\text { Wright and } \\
\text { Casamass-imo, } \\
2017 \text { [83]; USA }\end{array}$ & 1615 & $\begin{array}{l}\text { pediatric } \\
\text { dentists; } \\
\text { pediatric } \\
\text { dental } \\
\text { residents }\end{array}$ & $\begin{array}{l}\text { children; sugar } \\
\text { sweetened } \\
\text { beverages }\end{array}$ & $X^{\text {Practice/Prof }}$ & $x$ & $x$ & $x$ & $x$ \\
\hline $\begin{array}{c}\text { Cole et al., } \\
2018 \text { [84]; USA }\end{array}$ & 919 & $\begin{array}{c}\text { dental } \\
\text { hygienists }\end{array}$ & children & $X^{\text {Practice/Prof }}$ & $X^{\text {Practice/Prof }}$ & $x$ & & $X^{\text {Practice/Prof }}$ \\
\hline $\begin{array}{l}\text { Djokic et al., } \\
2019 \text { [85]; } \\
\text { Ireland }\end{array}$ & 467 & $\begin{array}{c}\text { pediatric } \\
\text { dentists; } \\
\text { nonpediatric } \\
\text { dentists }\end{array}$ & infants & $X^{\text {Professional Type }}$ & & & & \\
\hline $\begin{array}{c}\text { Aziz et al., } \\
2020 \text { [86]; New } \\
\text { Zealand }\end{array}$ & 325 & $\begin{array}{l}\text { general } \\
\text { dentists }\end{array}$ & & $X^{\text {Practice/Prof }}$ & & & & \\
\hline $\begin{array}{c}\text { Bakhurji et al., } \\
2021 \text { [87]; } \\
\text { Saudi Arabia }\end{array}$ & 335 & $\begin{array}{l}\text { general } \\
\text { dentists; } \\
\text { pediatric } \\
\text { dentists }\end{array}$ & infants & $X^{\text {Professional Type }}$ & & $X^{\text {Professional Type }}$ & & \\
\hline \multicolumn{9}{|c|}{ Dietitians/Nutritionists } \\
\hline $\begin{array}{l}\text { Shick et al., } \\
2005 \text { [88]; USA }\end{array}$ & 324 & $\begin{array}{c}\text { WIC } \\
\text { nutritionists }\end{array}$ & WIC clients & & & & & $\mathrm{X}^{\text {Patient; Practice/Prof }}$ \\
\hline $\begin{array}{l}\text { Butani et al., } \\
2006 \text { [89]; USA }\end{array}$ & 126 & WIC providers & WIC clients & $X^{\text {Practice/Prof }}$ & & & & \\
\hline $\begin{array}{l}\text { Fuller et al., } \\
2014 \text { [49]; USA }\end{array}$ & 159 & $\begin{array}{c}\text { WIC } \\
\text { personnel }\end{array}$ & WIC clients & & & $X^{\text {Practice/Prof }}$ & & $X^{\text {Practice/Prof }}$ \\
\hline $\begin{array}{c}\text { Gold and } \\
\text { Tomar, } \\
\text { 2016 [50]; USA }\end{array}$ & 9 & $\begin{array}{c}\text { WIC } \\
\text { nutritionists }\end{array}$ & WIC clients & & & $x$ & & $x$ \\
\hline $\begin{array}{l}\text { Fernandez } \\
\text { et al., } 2017 \text { [51]; } \\
\text { USA }\end{array}$ & 36 & $\begin{array}{l}\text { dietitians who } \\
\text { completed a } \\
\text { pediatric } \\
\text { dentistry } \\
\text { internship } \\
\text { rotation }\end{array}$ & & $x$ & & & $x$ & $x$ \\
\hline \multicolumn{9}{|c|}{ CHART REVIEW STUDIES } \\
\hline \multicolumn{9}{|c|}{ Oral Health Professionals } \\
\hline $\begin{array}{l}\text { Kärkkäinen } \\
\text { et al., } 2001 \text { [90]; } \\
\text { Finland }\end{array}$ & $\begin{array}{l}267 \text { in } 1992 ; \\
590 \text { in } 1995\end{array}$ & $\begin{array}{l}\text { public dental } \\
\text { service }\end{array}$ & $\begin{array}{c}\text { children } \\
12 \text { years and } \\
15 \text { years }\end{array}$ & $X^{\text {Patient}} ;$ Practice/Prof & & & & \\
\hline $\begin{array}{l}\text { Tickle et al., } \\
2003 \text { [91]; UK }\end{array}$ & 677 & $\begin{array}{c}\text { general dental } \\
\text { practices } \\
(n=50)\end{array}$ & $\begin{array}{l}\text { children who } \\
\text { regularly } \\
\text { attended } \\
\text { dental care } \\
\text { and have a } \\
\text { history of } \\
\text { interproximal } \\
\text { caries in } \\
\text { primary } \\
\text { molars }\end{array}$ & $\mathrm{X}^{\text {Patient }}$ & & & & \\
\hline $\begin{array}{c}\text { Nihtilä and } \\
\text { Widström, } \\
2009 \text { [92]; } \\
\text { Finland }\end{array}$ & 466 & $\begin{array}{l}\text { public dental } \\
\text { service }\end{array}$ & $\begin{array}{l}\text { children and } \\
\text { adolescents }\end{array}$ & $X^{\text {Patient }}$ & & & & \\
\hline
\end{tabular}


Table 4. Cont.

\begin{tabular}{|c|c|c|c|c|c|c|c|c|}
\hline $\begin{array}{c}\text { Study } \\
\text { Authors, Year, } \\
\text { and Country }\end{array}$ & Sample Size * & $\begin{array}{c}\text { Professional } \\
\text { Type }\end{array}$ & $\begin{array}{l}\text { Population } \\
\text { and/or } \\
\text { Concern of } \\
\text { Focus }\end{array}$ & $\begin{array}{c}\text { General/ } \\
\text { Unspecific } \\
\text { Intervention } \\
\text { Practices (e.g., } \\
\text { Nutrition } \\
\text { Counselling, } \\
\text { Diet Advice) }\end{array}$ & $\begin{array}{c}\text { Types of } \\
\text { Resources/ } \\
\text { Strategies } \\
\text { Used }\end{array}$ & $\begin{array}{c}\text { Information } \\
\text { Provided to } \\
\text { Patients }\end{array}$ & $\begin{array}{c}\text { Barriers } \\
\text { Regarding } \\
\text { Intervention } \\
\text { Practices }\end{array}$ & $\begin{array}{c}\text { Referrals/ } \\
\text { Collaboration } \\
\text { between } \\
\text { Dentistry and } \\
\text { Nutri- } \\
\text { tion/Dietetics }\end{array}$ \\
\hline \multicolumn{9}{|c|}{ CHART REVIEW STUDIES } \\
\hline \multicolumn{9}{|c|}{ Oral Health Professionals } \\
\hline $\begin{array}{l}\text { Wang and } \\
\text { Aspelund, } \\
2010 \text { [93]; } \\
\text { Norway }\end{array}$ & 576 & $\begin{array}{l}\text { public dental } \\
\text { service } \\
\text { (20 clinicians } \\
\text { in } 16 \text { public } \\
\text { dental service } \\
\text { clinics) }\end{array}$ & $\begin{array}{l}\text { children and } \\
\text { adolescents } \\
\text { 3-18 years }\end{array}$ & $X^{\text {Patient }}$ & & & & \\
\hline $\begin{array}{l}\text { Sarmadi et al., } \\
2011 \text { [94]; } \\
\text { Sweden }\end{array}$ & 432 & $\begin{array}{l}\text { public dental } \\
\text { service } \\
\text { (dentists and } \\
\text { dental } \\
\text { hygienists) }\end{array}$ & $\begin{array}{l}\text { children } \\
\text { 6-19 years at } \\
\text { high risk of } \\
\text { developing } \\
\text { dental caries }\end{array}$ & $X^{\text {Patient }}$ & & & & \\
\hline $\begin{array}{c}\text { Masoe et al., } \\
2014 \text { [95]; } \\
\text { Australia }\end{array}$ & 29,599 & $\begin{array}{l}\text { public dental } \\
\text { service (oral } \\
\text { health } \\
\text { therapists) }\end{array}$ & $\begin{array}{l}\text { adolescents } \\
12-18 \text { years }\end{array}$ & $X^{\text {Patient; Practice/Prof }}$ & & & & \\
\hline $\begin{array}{l}\text { Raindi et al., } \\
2015 \text { [96]; UK }\end{array}$ & & $\begin{array}{l}\text { general dental } \\
\text { practice }\end{array}$ & $\begin{array}{l}\text { periodontal } \\
\text { disease }\end{array}$ & $\mathrm{X}$ & & & & \\
\hline $\begin{array}{c}\text { Skinner et al., } \\
2016 \text { [97]; } \\
\text { Australia }\end{array}$ & $\begin{array}{c}\sim 26,000 \text { to } \\
\sim 31,000 \text { per } \\
\text { year }\end{array}$ & $\begin{array}{l}\text { public dental } \\
\text { service }\end{array}$ & $\begin{array}{l}\text { adolescents } \\
12-17 \text { years }\end{array}$ & $X^{\text {Patient }}$ & & & & \\
\hline \multicolumn{9}{|c|}{ OBSERVATION, CHART REVIEW, AND SURVEY STUDY } \\
\hline \multicolumn{9}{|c|}{ Oral Health Professionals } \\
\hline $\begin{array}{c}\text { Demko et al., } \\
2008 \text { [98]; } \\
\text { Wotman et al., } \\
2010 \text { [99]; USA }\end{array}$ & $\begin{array}{l}3751 \text { patient } \\
\text { visits in } \\
120 \text { general } \\
\text { dental } \\
\text { practices }\end{array}$ & $\begin{array}{c}\text { dentists, } \\
\text { dental } \\
\text { hygienists }\end{array}$ & & $X^{\text {Professional Type }}$ & & & & \\
\hline \multicolumn{9}{|c|}{ QUALITATIVE INTERVIEW AND/OR FOCUS GROUP STUDIES } \\
\hline \multicolumn{9}{|c|}{ Oral Health Professionals and Dietitians/Nutritionists } \\
\hline $\begin{array}{l}\text { Threlfall et al., } \\
2007 \text { [100]; } \\
\text { Threlfall et al., } \\
2007 \text { [54]; UK }\end{array}$ & 93 & $\begin{array}{l}\text { general dental } \\
\text { practitioners }\end{array}$ & $\begin{array}{c}\text { children; } \\
\text { dental caries }\end{array}$ & $\mathrm{X}^{\text {Patient; Practice/Prof }}$ & $x$ & $X^{\text {Patient }}$ & $x$ & \\
\hline $\begin{array}{l}\text { Cashmore } \\
\text { et al., } \\
2011 \text { [101]; } \\
\text { Australia }\end{array}$ & 10 & $\begin{array}{l}\text { dental } \\
\text { assistants, } \\
\text { dental } \\
\text { therapists, } \\
\text { pediatric } \\
\text { dental } \\
\text { specialist, } \\
\text { regional } \\
\text { co-ordinator of } \\
\text { oral health } \\
\text { promotion }\end{array}$ & $\begin{array}{l}\text { children } \\
\text { waiting for } \\
\text { surgery for } \\
\text { treatment of } \\
\text { severe dental } \\
\text { caries }\end{array}$ & & & & $\mathrm{x}$ & \\
\hline $\begin{array}{l}\text { Ong et al., } \\
2015 \text { [102]; } \\
\text { Hong Kong }\end{array}$ & 23 & $\begin{array}{l}\text { dentists, } \\
\text { dietitians }\end{array}$ & & & & & & $\mathrm{x}$ \\
\hline \multicolumn{9}{|c|}{$\begin{array}{l}\text { * Sample size for survey studies and qualitative interview and/or focus group studies refers to number of professionals included; sample } \\
\text { size for chart review and observational studies refers to the number of patients included. WIC: Special Supplemental Nutrition Program for } \\
\text { Women, Infants, and Children. (X) = study measure included both assessment and intervention practices combined together (e.g., analyzed } \\
\text { diets and gave dietary advice). Patient = examine differences in intervention practices in different types of patients (e.g., children vs. adults, } \\
\text { severe dental caries vs. not). Professional Type = examine differences in intervention practices in different types of professionals (e.g., } \\
\text { general dentists vs. pediatric dentists, dentists vs. dental hygienists). Practice/Prof = examine differences in intervention practices for } \\
\text { different practice characteristics (e.g., public vs. private, rural practice vs. urban practice) and/or health professional characteristics (e.g., } \\
\text { demographics, education, attitudes). }\end{array}$} \\
\hline
\end{tabular}

\section{General/Unspecific Nutrition Intervention Practices}

In total, $n=33$ cross-sectional survey studies presented in $n=36$ articles, $n=8$ chart review studies, $n=1$ observation study presented in $n=2$ articles, and $n=1$ qualitative interview study presented in $n=2$ articles provide information on the delivery of 
general/unspecific nutrition interventions (e.g., diet counselling, nutrition counselling, dietary advice, dietary instruction, providing information on diet, nutrition advice) by oral health professionals. In general, most of the survey studies that captured self-report information on this topic report on the proportion of oral health professionals providing this service with or without some type of measure of how often they provide this service. Of note, most of these studies reported information on dentists; however, there were eight studies that also captured information on the practices of other oral health professionals (e.g., dental hygienists, dental therapists, dental nurses) $[59,64,66,67,69,78,82,84]$. Overall, most of these studies find using a variety of different types of measures that many oral health professionals self-report carrying out nutrition interventions at least some of the time. However, within these survey studies, only a few studies captured information on the percentage of patients receiving this care and found it varied from a mean of $21.4 \%$ to $63.0 \%$ [43,74-76]. In addition, a few survey studies reported that the length of time spent on these activities was brief (approximately five minutes) [35,60].

In contrast to the cross-sectional survey studies which provide self-report data, the chart review studies (one of which includes professionals documenting all preventative activities over a 2-week time frame) and observation studies generally find that this practice is variable and often limited. For example, these studies conducted in children and adolescents have found that nutrition interventions are provided to a range of $<10 \%$ of children/adolescents to $>50 \%$ of children/adolescents in both public dental service and other practice settings [91-94,97], that dietary advice represented $<10 \%$ of clinical activities in public dental service [95], and that the number of diet instruction sessions is low in public dental clinics (e.g., $\leq \sim 1$ per child/adolescent in the observation periods) [90]. Of note, the study by Sarmadi et al. [94] also found that diet counselling was provided to $\sim 10-20 \%$ of children and adolescents whereas diet information was provided to $\sim 40-50 \%$ of children and adolescents attending public dental services in Sweden. In addition, Raindi et al. [96] found in a small pilot study that diet advice was not provided for periodontal prevention. As well, an observation study $[98,99]$ conducted in general dental practices in the United States found that overall $<\sim 10 \%$ of visits had nutrition counselling with the median number of $30 \mathrm{~s}$ intervals devoted to nutrition counselling being 0 (range: 0-6 for dentists; $0-23$ for dental hygienists). In addition, this study also found that among dentists and dental hygienists who self-reported often/always providing a nutrition discussion using a self-administered survey, only a mean of $3.9 \%$, and $13.7 \%$ of the patients of these dentists and dental hygienists, respectively, were observed to actually receive this service. In addition, when this practice occurred, $<5 \%$ of visit time was spent on this activity.

Very few studies provide information on how general/unspecific nutrition intervention practices of different types of oral health professionals compare to one another $[63,71,82,85,87,98,99]$. Overall, most of these studies found that pediatric dentists more commonly provided these interventions to infant patients compared to other dentists $[63,71,85,87]$ and that dental hygienists and/or oral health therapists provide these interventions more frequently compared to dentists $[82,98,99]$.

In total, 11 studies $[54,57,59,78,90-95,97]$ examined the provision of general/unspecific nutrition interventions by patient type. Six studies $[57,59,90-93]$ found that the provision of general/unspecific nutrition interventions generally increased as the severity of dental disease (e.g., dental caries, erosion), risk of dental disease, or amount of dental care increased; however, only three studies reported significant results $[90,91,93]$. Studies also found that in children and adolescent patients, those who are younger (vs. older) [95], those who are less disadvantaged when looking at socioeconomic status (vs. more disadvantaged) [97], and patients/families who the professional felt were more motivated and with whom they had seen success [54] were more likely to receive nutrition interventions from oral health professionals. In addition, one study found that the frequency of delivery of dietary advice by dental nurses was similar for children $<2$ years of age compared to children $>2$ years of age [78]. 
Seventeen survey studies presented in 19 articles investigated various professional and practice factors that impact the provision or the intent to provide general/unspecific nutrition interventions, with some of these studies finding statistically significant results. First, some studies found that oral health professional demographic variables showed some type of statistically significant relationship with the provision of general/unspecific nutrition interventions, including oral health professional age [79]; sex [73,75,79,86]; knowledge, skills, and/or education in this area [78,84]; and ownership of practice [73]. Studies have also found that attitudes, perceived behavioural control, motivation, and/or confidence in this area were statistically significantly associated with providing nutrition interventions $[40,41,60,75,78,83]$. A study of dental hygienists found that working more hours per week was associated with increased likelihood of providing nutrition counselling [69]. Studies also found that practice characteristics were statistically significantly associated with providing general/unspecific nutrition interventions, including prevention focus/orientation [75,76], practice location (e.g., rural vs. urban) [66], practice constraints [40], practice busyness [75], and practice type and setting (e.g., private vs. public; community dental service vs. general dental practice) $[33,65,67,86]$. Moreover, a chart review study of public dental services found that rural health districts provided less dietary advice compared to metropolitan health districts [95]. Lastly, Threlfall et al. [54] found in a qualitative study of general dental practitioners regarding care of children with dental caries that practices with a dental hygienist had an increased focus on providing diet advice.

\section{Types of Resources/Strategies Used}

Only a few studies $[43,54,55,60,83,84]$ reported on types of specific nutrition education materials, resources, and/or strategies used when oral health professionals provide nutrition interventions. Most of the studies that have investigated this topic have been cross-sectional survey studies that provide self-reported information. Chisick et al. [55] and Huang et al. [60] found that oral presentations/oral discussions and paper fliers/handouts were the most common ways to deliver this information. Huang et al. [60] reported on the frequency of providing nutrition advice to parents compared to children, and they found similar results between the two groups. In addition, Wright and Casamassimo [83] investigated in pediatric dentists and pediatric dental residents the frequency of using different types of intervention strategies to reduce consumption of sugar-sweetened beverages; they found that speaking to parents about observations if the child has high risk of dental caries was the most common strategy, followed by documenting the high risk of dental caries in the patient's chart. Provision of educational materials on sugar-sweetened beverages and offering motivational interviewing or other behaviour modification programs were also relatively common strategies. They further found that less common intervention strategies included providing parents with a self-administered sugar-sweetened beverage screening tool, and following up on interventions. Cole et al. [84] examined the frequency of provision of different types of nutrition interventions by dental hygienists. They found that nutrition counselling was more common than advocacy and collaborative activities (e.g., advocating to school officials to ensure healthy foods are available in school food services). For advocacy and collaborative activities, they also found that those with continuing education on obesity were more likely to do those activities compared to those who had obesity education only within an entry-level dental hygiene program. Arheiam et al. [43] also found that $40 \%$ of general dental practitioner respondents referred patients to other oral health professionals (e.g., dental hygienists) for advice on diet for an average of $11 \%$ of their patients. Lastly, Threlfall et al. [54] found in a qualitative study of general dental practitioners regarding caring for children with dental caries that oral advice was the most common way to provide dietary information, but providing leaflets was also done. They also found that general dental practices that had a dental hygienist often had preventative activities (e.g., diet advice) delegated to those professionals. 


\section{Types of Nutrition Information Provided}

Few details on the types of nutrition information provided to patients by oral health professionals were present in the included articles; only 10 survey studies reported this type of finding $[35,55-57,60,63,64,83,84,87]$. Topics that were captured in the survey studies included nursing caries/baby bottle decay risk $[55,63,87]$; consumption of sugary foods and drinks (including timing) [35,56,83,84]; consumption of between-meal snacks [84], supplements (including recommending vitamins) [35,64]; and consumption of erosion-causing foods, specifically carbonated soft drinks, fruit juice, acidic drinks, and citrus fruit [57]. In addition, Huang et al. [60] provided information on the proportion of orthodontists who provided patients handouts on foods to avoid ( $56 \%$ of respondents) and foods to encourage (32\% of respondents).

Very few studies examined differences between different types of oral health professionals for this type of finding. Brickhouse et al. [63] found that discussing baby bottle decay risk during infant oral health exams was common and similar between pediatric dentists and general dentists (pediatric dentists: $98 \%$; general dentists: $100 \%$ ). In addition, Bakhurji et al. [87] found that $60 \%$ of pediatric dentists and $64 \%$ of general dentists provided nutrition counselling and talked about baby bottle decay in infant oral health care. The work by Dugmore and Rock [57] was the only study to examine the proportion of dentists who provided specific dietary messages in different patient populations. They reported the proportions of dentists who provided advice on carbonated soft drinks, fruit juice, acidic drinks, and citrus fruit for patients presenting with tooth erosion into (a) the enamel and (b) the dentine. The percentage of dentists who gave the specific types of advice ranged from $6.6 \%$ to $31.7 \%$ depending on the food/beverage topic and whether the tooth erosion was into the enamel or dentine.

A qualitative interview study by Threlfall et al. [54,100] provided in-depth information on the content of dietary advice provided by general dental practitioners to children who are dealing with dental caries and their parents. In this study, all general dental practitioners reported providing dietary advice. Dietary advice was primarily centred on decreasing consumption of sugar, and sugar intake frequency was often considered a key message. Sugary beverages were also a common topic for dietary advice. The authors reported that there were variations in dietary advice content and emphasis (e.g., some participants provided advice on extrinsic sugars while others did not; some participants said to limit carbonated drinks due to erosion, and others said to reduce intake of these drinks because of sugar). Some participants also reported that they emphasized oral hygiene instead of diet because they felt it was easier to change, and some participants also reported trying to provide advice that was practical knowing that children like sugary foods and beverages (e.g., providing strategies on how to consume sugar-rich foods to decrease risk of caries). The authors also found that participants tailored the advice to parents based on their perception of the level of ignorance.

\section{Barriers Regarding Intervention Practices}

In total, six survey studies $[40,60,61,80,82,83]$ examined the prevalence of barriers associated with the provision of nutrition interventions by oral health professionals using quantitative methods; five studies examined these barriers in dentists $[40,60,61,82,83]$, and three studies examined these barriers in other types of oral health professionals (i.e., dental hygienists, oral health therapists) $[61,80,82]$. The most common barriers studied were compensation, funding, and/or reimbursement [40,60,61,80,82,83]; time [40,60,61,80,82,83]; lack of professional training, knowledge, and/or skills $[40,61,80,82,83]$; and patient motivation, compliance, and/or interest (including difficulties in changing behaviour) $[40,80,83]$. Other barriers examined in two studies included patient knowledge and demographics (e.g., literacy, education level, socioeconomic status) [80,82]; lack of trained staff $[40,83]$; lack of resources [60,83]; communication, language, and/or cultural barriers [60,82]; lack of likelihood of effectiveness or benefit [61,82]; and fear of judging, alienating, and/or offending patients $[61,83]$. Of note, time was among the top three most commonly reported 
barriers in four of those studies $[60,61,80,82]$. Additionally, lack of patient motivation, compliance, and/or interest (including difficulties in changing behaviour) $[40,80,83]$; compensation, funding, and/or reimbursement $[40,61,82]$; and lack of professional training, knowledge, and/or skills $[61,80,82]$ were among the top three most commonly reported barriers in three of those studies.

Dyer and Robinson [61] examined differences in the prevalence of perceived barriers reported by principal dentists to providing advice on diet/calorie intake by dentists and professionals complementary to dentistry (PCDs). The authors found statistically significant differences in the following barriers between the two types of professionals: time (dentists: $30.7 \%$; PCDs: $16.9 \%$ ) and lack of training/knowledge (dentists: $22.3 \%$; PCDs: $7.8 \%$ ). The authors found no differences for other investigated barriers (i.e., funding, effectiveness, patient alienation).

Two studies examined the relationship between barriers and implementation of nutrition interventions in pediatric dentists. Sim et al. [40] found that when practitioners were grouped into those who provide dietary recommendations all of the time and those who do not, those who provide dietary recommendations all of the time had a significantly lower proportion of respondents who reported the following barriers: infant/toddler oral health is not a practice focus, recommendations are confusing/ambiguous, deficiency of trained auxiliaries, and time constraints. Wright and Casamassimo [83] found in pediatric dentists and dental residents that there was a significant relationship between provision of interventions regarding sugar-sweetened beverages and several different barriers, including reimbursement, time, lack of knowledge/skills, concern about offending patients, lack of educational materials, and legal concerns.

In addition, three articles captured qualitative data using various methods (e.g., interviews, focus groups, open-ended survey questions) on barriers to providing nutrition interventions from the perspectives of oral health professionals [54,64,101]. Lack of oral health professional confidence and knowledge [64,101], lack of evidence-based guidance [64], funding and/or time [54,64], and lack of patient motivation and knowledge [54] were all identified.

\subsubsection{Dietitians and Nutritionists}

Four cross-sectional survey studies examined provision of interventions for oral health provided by dietitians or nutritionists (including WIC personnel) [49-51,89]. Importantly, three of these studies were conducted in WIC personnel $[49,50,89]$.

First, Butani et al. [89] assessed how often oral health was discussed by WIC personnel with clients. In total, they found that $37 \%$ of respondents discussed oral health issues most of the time or every time and $21 \%$ of respondents discussed it none of the time or a little of the time. They also found that $69 \%$ of respondents discussed oral health with more than $50 \%$ of their clients. Nursing training and oral health training were significant predictors for WIC personnel to discuss oral health with their clients. Fuller et al. [49] found that a significantly higher percentage of WIC personnel from rural districts self-reported advising parents/guardians on fluoride treatments or supplements compared to those from urban districts (rural: 58\%; urban: $42 \%$ ). Tooth brushing counselling provision in WIC clients by WIC personnel was assessed in two studies. Fuller et al. [49] found that more than $50 \%$ of surveyed WIC personnel provide tooth brushing counselling and that it was significantly related to practitioner years of experience. In addition, Gold and Tomar [50] found that $67 \%$ of WIC nutritionists frequently advise caregivers on the significance of frequent tooth brushing for their child. They also found that $67 \%$ of WIC nutritionists frequently advise caregivers on the importance of dental visits and $11 \%$ frequently discuss how the women's oral health and the child's oral health are linked. Gold and Tomar [50] also found that $100 \%$ of respondents frequently talk about how sugary drinks and snacks have a role in dental caries.

Only one study examined the intervention practices of dietitians outside of a WIC setting related to oral health. Fernandez et al. [51] surveyed dietitians who completed an 
elective pediatric dentistry rotation during their dietetic internship training. This study found that among participants, $20 \%$ always and $20 \%$ never include information about oral health as part of diet counselling; $40 \%$ always and $17 \%$ never consider the impact on oral health when recommending healthy foods; $34 \%$ always and $14 \%$ never consider the impact on teeth when providing counselling regarding sugary beverages. The authors also found that $17 \%$ always and $34 \%$ never provide education on oral health.

The study of Fernandez et al. [51] was the only study that provided information on the perceived barriers of dietitians in providing their services to dental patients. They investigated different types of barriers, and their results are as follows: cost/reimbursement of dietitian services (significant barrier: $57 \%$ of respondents; possible barrier: $43 \%$ ), interest of clients in diet and oral health (significant barrier: $29 \%$; possible barrier: $63 \%$; not a barrier: $9 \%$ ), dentist reluctance to refer their patients to a dietitian (significant barrier: $37 \%$; possible barrier: $51 \%$; not a barrier: $11 \%$ ), and dietitian confidence in providing counselling and/or information in this area (possible barrier: $62 \%$; not a barrier: $38 \%$ ).

\subsubsection{Collaboration between Dietitians and Oral Health Professionals}

Cross-sectional survey studies of oral health professionals investigated collaboration between nutrition/dietetics and dentistry using various outcomes, including referrals to dietitians/nutritionists $[35,60,83,84]$, nutrition referrals [55,60], and/or recommendation of dietetics [81]. Although slightly different outcomes were used, they reported that the majority of oral health professionals never provide referrals to dietitians/nutritionists.

Four survey studies examined referrals to dentists by dietitians, nutritionists and/or WIC personnel [49-51,88]; three of those studies were conducted in WIC personnel [49,50,88]. For example, Gold and Tomar [50] found that $44 \%$ of WIC nutritionists frequently referred children or women to dental care. Fuller et al. [49] found that a significantly higher percentage of WIC personnel from urban districts referred clients to a dentist compared to those from rural districts (urban: $54 \%$; rural: $46 \%$ ). Shick et al. [88] comprehensively studied the dental care referral practices of WIC personnel. The authors found that $95.6 \%$ of respondents reported making dental referrals for children 1-5 years, and of those, 52.3\% conducted this activity very frequently or frequently; referrals for infants were much less common. These authors also found that statistically significant predictors of referring children aged $1-5$ years to dental care included older practitioner age (i.e., $\geq 40$ years vs. younger), higher frequency of seeing dental concerns in patients (vs. lower), higher frequency of parents asking about obtaining dental care for their children (vs. lower), higher confidence in performing oral health risk assessment (vs. lower), higher confidence in making dental referrals (vs. lower), and higher confidence that patients will access dental care if advised (vs. lower). This study also reported that the most often used referral locations were local health departments (60.3\% of respondents) and private dental offices (31.7\% of respondents). The study of Fernandez et al. [51] was the only survey study that examined referrals to oral health professionals by dietitians outside of a WIC setting. The authors found that $54 \%$ of dietitians referred patients to pediatric or general dentists in their practice.

The qualitative study by Ong et al. [102] examined interdisciplinary collaboration between dietitians, dentists, and physicians in Hong Kong in regards to diet. The authors found that barriers included those associated with electronic health records (e.g., not used by all the different professions), limited contact between the professions, lack of financial coverage, and inconsistent diet advice between different professions due to a lack of understanding of the advice given by others and different focuses of treatment administered by the different professions. Ideas presented to facilitate collaboration included more collaboration in undergraduate education, interprofessional education events, and development of guidelines with input from different professions. 


\section{Discussion}

To our knowledge, this is the first scoping review to comprehensively examine the literature on the nutrition care practices of oral health professionals and dietitians/nutritionists to optimize oral health (and specifically conditions that affect the dentition and periodontium). This review provides valuable information on the types of published evidence available in this area and a summary of key findings of these studies. The information gathered through conducting this review helps to provide direction on future strategies needed to move this area of research forward, which is important as oral health issues are prevalent in Canada and worldwide.

Although there appears to be substantial interest in this topic due to the volume of studies published that report information in this area, most articles provide only general and unspecific findings (e.g., capturing how often oral health professionals provide dietary advice) and focus mainly on oral health professionals (and especially dentists). Most of the data are also self-reported, which has limitations. Moreover, more than half of the studies were conducted in two regions (the United States and the United Kingdom), and there was only one study from Canada. In addition, many more studies focus on intervention practices compared to assessment practices despite assessment being an essential component to develop an appropriate intervention plan. Of note, very few studies provided specific details about the nutrition care encounters (e.g., types of dietary assessment tools used, types of information provided to patients, strategies used to provide the information, length of time spent on the encounter, follow-up on encounters). A consideration for future research in this area is that the standardized Nutrition Care Process (NCP) could be used when thinking about how to approach conducting research on this topic. This framework was developed by the Academy of Nutrition and Dietetics (formerly the American Dietetic Association) [103] and distinguishes nutrition care into four components: Nutrition Assessment, Nutrition Diagnosis, Nutrition Intervention, and Nutrition Monitoring and Evaluation. Use of this framework may be useful for structuring future research in this area.

Several studies did not specifically outline the oral health issue and patient population that was being studied; when studies examined nutrition care practices in oral health professionals, it was assumed that they were referring to oral health (and specifically the dentition and periodontium). Although this assumption is likely relatively safe, a limitation of this review is that through the process of conducting this project, we found evidence that oral health professionals may also provide some nutrition care in other areas such as diabetes [104,105] and obesity/weight management [106-109]. We felt that the inclusion of these articles that did not mention the specific oral health condition and patient population was important as they represent an important group of studies in this area.

Another interesting finding from this review was that information on nutrition care practices for oral health (and specifically the dentition and periodontium) was captured using various study designs both in terms of the research methodology (e.g., cross-sectional survey, observation, chart review, qualitative interview) and the overall focus of the articles. In addition, many studies collecting information on nutrition care practices of oral health professionals capture this information as part of a study with a non-nutrition focus such as examining overall practice patterns of oral health professionals (e.g., $[66,67])$, dental prevention activities (including for dental caries) (e.g., $[41,42,55,58,59,77,79])$, or infant oral health care (e.g., $[36,63,68,70,71,85,87])$. However, a few studies focused primarily on diet and oral health (e.g., $[35,40,43,75,80,82])$. Because diet was often not the focus of the included studies (and instead a subcomponent), one major challenge encountered when conducting this review was that many of the included articles were difficult to locate solely from database searching. As can be seen in Figure 1, many articles were located using other approaches (e.g., citations, hand searching). With diet being such an important component of optimal oral health, researchers conducting work in this area should consider including words related to diet/nutrition in the title, abstract, and keywords of articles to ensure that these studies will be found using database searches. In addition, more studies with 
a focus on diet and oral health should be conducted to focus on these specific activities, particularly because these activities are complex and multifaceted.

Overall, most of the articles included in this review found that nutrition care is provided by most oral health professionals at least some of the time. Survey studies and studies capturing self-report data found that provision of nutrition care was more common compared to when it was examined in chart review and observation studies. Some studies included as part of this review provide information on both barriers to providing nutrition care by oral health professionals and factors that affect the provision of these types of services, including the professional type, patient type, and various professional and practice factors. Together, this information suggests that many different factors can influence whether professionals provide this type of service and that there are many barriers that they experience when attempting to provide this type of care. This information is helpful for both dietitians and oral health professionals aspiring to provide this care, as well as managers interested in facilitating this process in different types of practice settings. Capturing this type of information in future studies is important to help optimize the provision of these types of services.

Dietitians are a professional group possessing the capability to offer substantial support in this area and have the knowledge, expertise, and time to focus on providing nutrition care to individuals who are in need of improving their diet to optimize oral health. Nutrition care by dietitians may also be a solution to address some of the barriers to performing these types of interventions identified by oral health professionals, including time (as they have more time to devote to nutrition care); lack of patient motivation, compliance, and/or interest (as they are trained to provide nutrition care to address these barriers such as motivational interviewing); and lack of knowledge/confidence among oral health professionals in providing this type of care (as dietitians are specifically trained to provide nutrition care). Despite the skillset of dietitians, this review identified only a handful of studies that captured information on nutrition care for oral health provided by dietitians and collaboration between dietitians and oral health professionals. Importantly, within the studies identifying collaboration between dietitians and dental professionals, findings suggest that this activity is uncommon despite various organizations and peer-review articles highlighting the importance of collaboration between these professionals $[8,110,111]$. In addition, dietitians have identified barriers in this area, including cost, lack of client interest in this area, dietitian confidence in providing support in this area, and concerns about reluctance of oral health professions to provide referrals to dietitians. Finding new ways to stimulate collaboration between the different professions will likely be very important in this area and overcoming barriers in this area is needed. Increased training on this topic for both professionals and students is important to consider.

There are a few limitations of this review. Although we did our best to locate articles using different strategies and are confident that we were able to locate the vast majority of the research studies in this area that met inclusion criteria, there are likely articles that were missed. Only studies written in English were included; there could have been relevant studies available in other languages that may have been excluded. We also did not assess nutrition care practices regarding oral health by professionals other than oral health professionals and dietitians, and there may be others who also provide these services. In addition, this review did not assess study quality.

\section{Conclusions}

Many different types of studies have captured information on nutrition care practices related to oral health (and specifically dentition and periodontium) in oral health professionals, and very few are available focusing on dietitians. In addition, there are limited data available on the specific details of the care that is provided. Few studies have captured information on interprofessional collaboration between dietitians and oral health professionals. This review article provides insight into how to move this area of research forward. 
Author Contributions: Conceptualization, J.R.L.L.; methodology, J.R.L.L., A.G.T.V., J.R.d.M. and A.C.; formal analysis, J.R.L.L., A.G.T.V., J.R.d.M. and A.C.; investigation, J.R.L.L., A.G.T.V., J.R.d.M. and A.C.; writing—original draft preparation, J.R.L.L.; writing—review and editing, A.G.T.V., J.R.d.M. and A.C.; project administration, J.R.L.L. All authors have read and agreed to the published version of the manuscript.

Funding: J. Rover de Mello was funded by a New Faculty Graduate Student Support Program Scholarship from the University of Saskatchewan, a Saskatchewan Centre for Patient Oriented Research Traineeship, and through a Saskatchewan Health Research Foundation Establishment Grant awarded to JRLL. A. Vanzan was funded by a Saskatchewan Centre for Patient Oriented Research Traineeship. An undergraduate student who assisted with article screening was funded by a Saskatchewan Health Research Foundation Establishment Grant awarded to JRLL.

Acknowledgments: We would like to thank Jenna Thomson for her assistance with screening articles for this review. In addition, we would like to thank Megan Kennedy and Vicky Duncan (health science librarians) for their advice with the literature searches. The funders had no role in scoping review design, data collection and analysis, decision to publish, or manuscript preparation.

Conflicts of Interest: The authors declare no conflict of interest. The funders had no role in the design of the study; in the collection, analyses, or interpretation of data; in the writing of the manuscript; or in the decision to publish the results.

\section{References}

1. James, S.L.; Abate, D.; Abate, K.H.; Abay, S.M.; Abbafati, C.; Abbasi, N.; Abbastabar, H.; Abd-Allah, F.; Abdela, J.; Abdelalim, A.; et al. Global, regional, and national incidence, prevalence, and years lived with disability for 354 diseases and injuries for 195 countries and territories, 1990-2017: A systematic analysis for the Global Burden of Disease Study 2017. Lancet 2018, 392, 1789-1858. [CrossRef]

2. Bernabe, E.; Marcenes, W.; Hernandez, C.R.; Bailey, J.; Abreu, L.G.; Alipour, V.; Amini, S.; Arabloo, J.; Arefi, Z.; Arora, A.; et al. Global, Regional, and National Levels and Trends in Burden of Oral Conditions from 1990 to 2017: A Systematic Analysis for the Global Burden of Disease 2017 Study. J. Dent. Res. 2020, 99, 362-373. [PubMed]

3. Health Canada. Report on the Findings of the Oral Health Component of the Canadian Health Measures Survey 2007-2009; Health Canada: Ottawa, ON, Canada, 2010; ISBN 9781100156606.

4. Schroth, R.J.; Quiñonez, C.; Shwart, L.; Wagar, B. Treating Early Childhood Caries under General Anesthesia: A National Review of Canadian Data. J. Can. Dent. Assoc. 2016, 82, g20. [PubMed]

5. World Health Organization. Oral Health. 2020. Available online: https://www.who.int/news-room/fact-sheets/detail/oralhealth (accessed on 30 September 2021).

6. Jensen, M.E. Diet and dental caries. Dent. Clin. N. Am. 1999, 43, 615-633.

7. Touger-Decker, R.; van Loveren, C. Sugars and dental caries. Am. J. Clin. Nutr. 2003, 78, 881S-892S. [CrossRef]

8. Touger-Decker, R.; Mobley, C. Position of the Academy of Nutrition and Dietetics: Oral health and nutrition. J. Acad. Nutr. Diet. 2013, 113, 693-701. [CrossRef]

9. Moynihan, P.J. Dietary advice in dental practice. Br. Dent. J. 2002, 193, 563-568. [CrossRef]

10. Salas, M.M.S.; Nascimento, G.G.; Vargas-Ferreira, F.; Tarquinio, S.B.C.; Huysmans, M.C.D.N.J.M.; Demarco, F.F. Diet influenced tooth erosion prevalence in children and adolescents: Results of a meta-analysis and meta-regression. J. Dent. 2015, 43, 865-875. [CrossRef]

11. Buzalaf, M.A.R.; Magalhães, A.C.; Rios, D. Prevention of erosive tooth wear: Targeting nutritional and patient-related risks factors. Br. Dent. J. 2018, 224, 371-378. [CrossRef]

12. Palmer, C.A. Important Relationships Between Diet, Nutrition, and Oral Health. Nutr. Clin. Care 2001, 4, 4-14. [CrossRef]

13. Tinanoff, N.; Palmer, C.A. Dietary determinants of dental caries and dietary recommendations for preschool children. J. Public Health Dent. 2000, 60, 197-199. [CrossRef]

14. Moynihan, P.; Petersen, P.E. Diet, nutrition and the prevention of dental diseases. Public Health Nutr. 2004, 7, 201-226. [CrossRef]

15. Scardina, G.A.; Messina, P. Good oral health and diet. J. Biomed. Biotechnol. 2012, 2012, 720692. [CrossRef]

16. Najeeb, S.; Zafar, M.S.; Khurshid, Z.; Zohaib, S.; Almas, K. The Role of Nutrition in Periodontal Health: An Update. Nutrients 2016, 8, 530. [CrossRef]

17. Bhattacharya, P.T.; Misra, S.R.; Hussain, M. Nutritional Aspects of Essential Trace Elements in Oral Health and Disease: An Extensive Review. Scientifica 2016, 2016, 5464373. [CrossRef]

18. Dietitians Association of Australia; Dental Health Services Victoria. Joint Position Statement on Oral Health and Nutrition October 2015. 2015. Available online: https://dietitiansaustralia.org.au/wp-content/uploads/2016/05/DAA-DHSV-JointStatement-Oral-Health-and-Nutrition.pdf (accessed on 30 September 2021).

19. NHS Health Scotland. Oral Health and Nutrition Guidance for Professionals June 2012. 2012. Available online: https://www. scottishdental.org/wp-content/uploads/2014/10/OralHealthAndNutritionGuidance.pdf (accessed on 30 September 2021). 
20. American Academy of Pediatric Dentistry Clinical Affairs Committee; American Academy of Pediatric Dentistry Council on Clinical Affairs. Policy on Dietary Recommendations for Infants, Children, and Adolescents. Pediatr. Dent. 2017, 39, 64-66.

21. Jones, A.C.; Kirkpatrick, S.I.; Hammond, D. Beverage consumption and energy intake among Canadians: Analyses of 2004 and 2015 national dietary intake data. Nutr. J. 2019, 18, 60. [CrossRef]

22. Canadian Dental Association. CDA Position on Early Childhood Caries. 2010. Available online: https://www.cda-adc.ca/en/ about/position_statements/ecc/ (accessed on 30 September 2021).

23. Canadian Dental Association. The State of Oral Health in Canada. 2017. Available online: https://www.cda-adc.ca/ stateoforalhealth/_files/TheStateofOralHealthinCanada.pdf (accessed on 30 September 2021).

24. Petersen, P.E. Global policy for improvement of oral health in the 21st century-implications to oral health research of World Health Assembly 2007, World Health Organization. Community Dent. Oral Epidemiol. 2009, 37, 1-8. [CrossRef]

25. Franki, J.; Hayes, M.J.; Taylor, J.A. The provision of dietary advice by dental practitioners: A review of the literature. Community Dent. Health 2014, 31, 9-14.

26. Arksey, H.; O’Malley, L. Scoping studies: Towards a methodological framework. Int. J. Soc. Res. Methodol. 2005, 8, 19-32. [CrossRef]

27. Levac, D.; Colquhoun, H.; O’Brien, K.K. Scoping studies: Advancing the methodology. Implement. Sci. 2010, 5, 69. [CrossRef]

28. FDI. World Dental Federation FDI's Definition of Oral Health. Available online: https://www.fdiworlddental.org/fdis-definitionoral-health (accessed on 12 May 2021).

29. Suga, U.S.G.; Terada, R.S.S.; Ubaldini, A.L.M.; Fujimaki, M.; Pascotto, R.C.; Batilana, A.P.; Pietrobon, R.; Vissoci, J.R.N.; Rodrigues, C.G. Factors that drive dentists towards or away from dental caries preventive measures: Systematic review and metasummary. PLoS ONE 2014, 9, e107831. [CrossRef]

30. Kay, E.; Vascott, D.; Hocking, A.; Nield, H.; Dorr, C.; Barrett, H. A review of approaches for dental practice teams for promoting oral health. Community Dent. Oral Epidemiol. 2016, 44, 313-330. [CrossRef]

31. U.S Department of Agriculture Food and Nutrition Service. Special Supplemental Nutrition Program for Women, Infants, and Children (WIC). Available online: https:/ / www.fns.usda.gov/wic (accessed on 30 September 2021).

32. Ouzzani, M.; Hammady, H.; Fedorowicz, Z.; Elmagarmid, A. Rayyan-A web and mobile app for systematic reviews. Syst. Rev. 2016, 5, 210. [CrossRef]

33. Roshan, D.; Curzon, M.E.J.; Fairpo, C.G. Changes in dentists' attitudes and practice in paediatric dentistry. Eur. J. Paediatr. Dent. 2003, 4, 21-27.

34. Hawkins, R.J.; Locker, D. Non-clinical information obtained by dentists during initial examinations of older adult patients. Spec. Care Dent. 2005, 25, 12-18. [CrossRef]

35. Sajnani-Oommen, G.; Perez-Spiess, S.; Julliard, K. Comparison of nutritional counseling between provider types. Pediatr. Dent. 2006, 28, 369-374.

36. Bubna, S.; Perez-Spiess, S.; Cernigliaro, J.; Julliard, K. Infant oral health care: Beliefs and practices of American Academy of Pediatric Dentistry members. Pediatr. Dent. 2012, 34, 203-209.

37. Clovis, J.B.; Horowitz, A.M.; Kleinman, D.V.; Wang, M.Q.; Massey, M. Maryland dental hygienists' knowledge, opinions and practices regarding dental caries prevention and early detection. J. Dent. Hyg. 2012, 86, 292-305.

38. Mulic, A.; Vidnes-Kopperud, S.; Skaare, A.B.; Tveit, A.B.; Young, A. Opinions on Dental Erosive Lesions, Knowledge of Diagnosis, and Treatment Strategies among Norwegian Dentists: A Questionnaire Survey. Int. J. Dent. 2012, 2012, 716396. [CrossRef]

39. Garton, B.J.; Ford, P.J. Root caries: A survey of Queensland dentists. Int. J. Dent. Hyg. 2013, 11, 216-225. [CrossRef] [PubMed]

40. Sim, C.J.; Iida, H.; Vann, W.F.J.; Quinonez, R.B.; Steiner, M.J. Dietary recommendations for infants and toddlers among pediatric dentists in North Carolina. Pediatr. Dent. 2014, 36, 322-328. [PubMed]

41. Yusuf, H.; Kolliakou, A.; Ntouva, A.; Murphy, M.; Newton, T.; Tsakos, G.; Watt, R.G. Predictors of dentists' behaviours in delivering prevention in primary dental care in England: Using the theory of planned behaviour. BMC Health Serv. Res. 2016, 16, 44. [CrossRef] [PubMed]

42. Widström, E.; Tillberg, A.; Byrkjeflot, L.I.; Skudutyte-Rysstad, R. Chair-side preventive interventions in the Public Dental Service in Norway. Br. Dent. J. 2016, 221, 179-185. [CrossRef] [PubMed]

43. Arheiam, A.; Brown, S.L.; Burnside, G.; Higham, S.M.; Albadri, S.; Harris, R.V. The use of diet diaries in general dental practice in England. Community Dent. Health 2016, 33, 267-273.

44. Halawany, H.S.; Salama, F.; Jacob, V.; Abraham, N.B.; Moharib, T.N.; Alazmah, A.S.; Al Harbi, J.A. A survey of pediatric dentists caries-related treatment decisions and restorative modalities-A web-based survey. Saudi Dent. J. 2017, 29, 66-73. [CrossRef] [PubMed]

45. Dima, S.; Chang, W.-J.; Chen, J.-W.; Teng, N.-C. Early Childhood Caries-Related Knowledge, Attitude, and Practice: Discordance between Pediatricians and Dentists toward Medical Office-Based Prevention in Taiwan. Int. J. Environ. Res. Public Health 2018, 15, 1067. [CrossRef]

46. Mulic, A.; Arnadottir, I.B.; Jensdottir, T.; Kopperud, S.E. Opinions and Treatment Decisions for Dental Erosive Wear: A Questionnaire Survey among Icelandic Dentists. Int. J. Dent. 2018, 2018, 8572371. [CrossRef]

47. Kangasmaa, H.; Tanner, T.; Laitala, M.-L.; Mulic, A.; Kopperud, S.E.; Vähänikkilä, H.; Anttonen, V.; Alaraudanjoki, V. Knowledge on and treatment practices of erosive tooth wear among Finnish dentists. Acta Odontol. Scand. 2021, 79, 499-505. [CrossRef] 
48. Mortensen, D.; Mulic, A.; Pallesen, U.; Twetman, S. Awareness, knowledge and treatment decisions for erosive tooth wear: A case-based questionnaire among Danish dentists. Clin. Exp. Dent. Res. 2021, 7, 56-62. [CrossRef]

49. Fuller, L.A.; Stull, S.C.; Darby, M.L.; Tolle, S.L. Oral health promotion: Knowledge, confidence, and practices in preventing early-severe childhood caries of Virginia WIC program personnel. J. Dent. Hyg. 2014, 88, 130-140. [PubMed]

50. Gold, J.T.; Tomar, S. Oral Health Knowledge and Practices of WIC Staff at Florida WIC Program. J. Community Health 2016, 41, 612-618. [CrossRef] [PubMed]

51. Fernandez, J.B.; Ahearn, K.; Atar, M.; More, F.G.; Sasson, L.; Rosenberg, L.; Godfrey, E.; Sehl, R.; Daronch, M. Interprofessional Educational Experience among Dietitians after a Pediatric Dentistry Clinical Rotation. Top. Clin. Nutr. 2017, 32, 193-201. [CrossRef]

52. Sarmadi, R.; Gabre, P.; Gahnberg, L. Strategies for caries risk assessment in children and adolescents at public dental clinics in a Swedish county. Int. J. Paediatr. Dent. 2009, 19, 135-140. [CrossRef]

53. O'Toole, S.; Khan, M.; Patel, A.; Patel, N.J.; Shah, N.; Bartlett, D.; Movahedi, S. Tooth wear risk assessment and care-planning in general dental practice. Br. Dent. J. 2018, 224, 358-362. [CrossRef]

54. Threlfall, A.G.; Hunt, C.M.; Milsom, K.M.; Tickle, M.; Blinkhorn, A.S. Exploring factors that influence general dental practitioners when providing advice to help prevent caries in children. Br. Dent. J. 2007, 202, E10; discussion 216-217. [CrossRef]

55. Chisick, M.C.; Richter, P.; Piotrowski, M.J. Dental health promotion and preventive dentistry practices of U.S. Army dentists. Mil. Med. 2000, 165, 604-606. [CrossRef]

56. Anderson, R.; Treasure, E.T.; Sprod, A.S. Oral health promotion practice: A survey of dental professionals in Wales. Int. J. Health Promot. Educ. 2002, 40, 9-14. [CrossRef]

57. Dugmore, C.R.; Rock, W.P. Awareness of tooth erosion in 12 year old children and primary care dental practitioners. Community Dent. Health 2003, 20, 223-227.

58. Freeman, R.; Kerr, G.; Salmon, K.; Speedy, P. Patient-active prevention in primary dental care: A characterisation of general practices in Northern Ireland. Prim. Dent. Care 2005, 12, 42-46. [CrossRef]

59. Wang, N.J. Caries preventive methods in child dental care reported by dental hygienists, Norway, 1995 and 2004 . Acta Odontol. Scand. 2005, 63, 330-334. [CrossRef]

60. Huang, J.S.; Becerra, K.; Walker, E.; Hovell, M.F. Childhood overweight and orthodontists: Results of a survey. J. Public Health Dent. 2006, 66, 292-294. [CrossRef]

61. Dyer, T.A.; Robinson, P.G. General health promotion in general dental practice-The involvement of the dental team Part 2: A qualitative and quantitative investigation of the views of practice principals in South Yorkshire. Br. Dent. J. 2006, 201, 45-51; discussion 31. [CrossRef]

62. Trueblood, R.; Kerins, C.A.; Seale, N.S. Caries risk assessment practices among Texas pediatric dentists. Pediatr. Dent. 2008, 30, 49-53.

63. Brickhouse, T.H.; Unkel, J.H.; Kancitis, I.; Best, A.M.; Davis, R.D. Infant oral health care: A survey of general dentists, pediatric dentists, and pediatricians in Virginia. Pediatr. Dent. 2008, 30, 147-153.

64. Kelly, S.A.M.; Moynihan, P.J. Attitudes and practices of dentists with respect to nutrition and periodontal health. Br. Dent. J. 2008, 205, E9; discussion 196-197. [CrossRef]

65. Csikar, J.; Williams, S.A.; Beal, J. Do smoking cessation activities as part of oral health promotion vary between dental care providers relative to the NHS/private treatment mix offered? A study in West Yorkshire. Prim. Dent. Care 2009, 16, 45-50. [CrossRef]

66. Satur, J.; Gussy, M.; Marino, R.; Martini, T. Patterns of dental therapists' scope of practice and employment in Victoria, Australia. J. Dent. Educ. 2009, 73, 416-425. [CrossRef] [PubMed]

67. Tseveenjav, B.; Virtanen, J.I.; Wang, N.J.; Widström, E. Working profiles of dental hygienists in public and private practice in Finland and Norway. Int. J. Dent. Hyg. 2009, 7, 17-22. [CrossRef] [PubMed]

68. Malcheff, S.; Pink, T.C.; Sohn, W.; Inglehart, M.R.; Briskie, D. Infant oral health examinations: Pediatric dentists' professional behavior and attitudes. Pediatr. Dent. 2009, 31, 202-209. [CrossRef] [PubMed]

69. Manski, M.C.; Parker, M.E. Early childhood caries: Knowledge, attitudes, and practice behaviors of Maryland dental hygienists. J. Dent. Hyg. 2010, 84, 190-195.

70. Salama, F.; Kebriaei, A. Oral care for infants: A survey of Nebraska general dentists. Gen. Dent. 2010, 58, $182-187$.

71. Ananaba, N.; Malcheff, S.; Briskie, D.; Inglehart, M.R. Infant oral health examinations: Attitudes and professional behavior of general and pediatric dentists in Michigan and pediatric dentists in the U.S. J. Mich. Dent. Assoc. 2010, 92, $38-43$.

72. Cunha-Cruz, J.; Wataha, J.C.; Zhou, L.; Manning, W.; Trantow, M.; Bettendorf, M.M.; Heaton, L.J.; Berg, J. Treating dentin hypersensitivity: Therapeutic choices made by dentists of the northwest PRECEDENT network. J. Am. Dent. Assoc. 2010, 141, 1097-1105. [CrossRef]

73. Lee, J.Y.; Caplan, D.J.; Gizlice, Z.; Ammerman, A.; Agans, R.; Curran, A.E. US pediatric dentists' counseling practices in addressing childhood obesity. Pediatr. Dent. 2012, 34, 245-250.

74. Kakudate, N.; Sumida, F.; Matsumoto, Y.; Manabe, K.; Yokoyama, Y.; Gilbert, G.H.; Gordan, V.V. Restorative treatment thresholds for proximal caries in dental PBRN. J. Dent. Res. 2012, 91, 1202-1208. [CrossRef]

75. Yokoyama, Y.; Kakudate, N.; Sumida, F.; Matsumoto, Y.; Gilbert, G.H.; Gordan, V.V. Dentists' dietary perception and practice patterns in a dental practice-based research network. PLOS ONE 2013, 8, e59615. [CrossRef] 
76. Yokoyama, Y.; Kakudate, N.; Sumida, F.; Matsumoto, Y.; Gilbert, G.H.; Gordan, V.V. Dentists' practice patterns regarding caries prevention: Results from a dental practice-based research network. BMJ Open 2013, 3, e003227. [CrossRef]

77. Hussein, R.J.; Schneller, T.; Walter, U. Preventive activity of dentists and its associations with dentist and dental practice characteristics in northern Germany. J. Public Health 2013, 21, 455-463. [CrossRef]

78. Gnich, W.; Deas, L.; Mackenzie, S.; Burns, J.; Conway, D.I. Extending dental nurses' duties: A national survey investigating skill-mix in Scotland's child oral health improvement programme (Childsmile). BMC Oral Health 2014, 14, 137. [CrossRef]

79. Yusuf, H.; Tsakos, G.; Ntouva, A.; Murphy, M.; Porter, J.; Newton, T.; Watt, R.G. Differences by age and sex in general dental practitioners' knowledge, attitudes and behaviours in delivering prevention. Br. Dent. J. 2015, 219, E7. [CrossRef] [PubMed]

80. Hayes, M.J.; Wallace, J.P.; Coxon, A. Attitudes and barriers to providing dietary advice: Perceptions of dental hygienists and oral health therapists. Int. J. Dent. Hyg. 2016, 14, 255-260. [CrossRef] [PubMed]

81. Baatsch, B.; Zimmer, S.; Rodrigues Recchia, D.; Bussing, A. Complementary and alternative therapies in dentistry and characteristics of dentists who recommend them. Complement. Ther. Med. 2017, 35, 64-69. [CrossRef] [PubMed]

82. Hayes, M.J.; Cheng, B.; Musolino, R.; Rogers, A.A. Dietary analysis and nutritional counselling for caries prevention in dental practise: A pilot study. Aust. Dent. J. 2017, 62, 485-492. [CrossRef]

83. Wright, R.; Casamassimo, P.S. Assessing attitudes and actions of pediatric dentists toward childhood obesity and sugar-sweetened beverages. J. Public Health Dent. 2017, 77 (Suppl. S1), S79-S87. [CrossRef]

84. Cole, D.D.M.; Boyd, L.D.; Vineyard, J.; Giblin-Scanlon, L.J. Childhood Obesity: Dental hygienists' beliefs attitudes and barriers to patient education. J. Dent. Hyg. 2018, 92, 38-49.

85. Djokic, J.; Bowen, A.; Dooa, J.S.; Kahatab, R.; Kumagai, T.; McKee, K.; Tan, C.; FitzGerald, K.; Duane, B.; Sagheri, D. Knowledge, attitudes and behaviour regarding the infant oral health visit: Are dentists in Ireland aware of the recommendation for a first visit to the dentist by age 1 year? Eur. Arch. Paediatr. Dent. 2018, 20, 65-72. [CrossRef]

86. Aziz, S.A.; Kuan, S.; Jin, E.; Loch, C.; Thomson, W.M. Do as I say and not as I do? New Zealand dentists' oral health practices and advice to patients. J. R. Soc. N. Z. 2020, 50, 178-188. [CrossRef]

87. Bakhurji, E.A.; Al-Saif, H.M.; Al-Shehri, M.A.; Al-Ghamdi, K.M.; Hassan, M.M. Infant Oral Healthcare and Anticipatory Guidance Practices among Dentists in a Pediatric Care Shortage Area. Int. J. Dent. 2021, 2021, 6645279. [CrossRef]

88. Shick, E.A.; Lee, J.Y.; Rozier, R.G. Determinants of Dental Referral Practices Among WIC Nutritionists in North Carolina. J. Public Health Dent. 2005, 65, 196-202. [CrossRef]

89. Butani, Y.; RA, K.; Qian, F.; Lampiris, L. Predictors of oral health counseling by WIC providers. J. Dent. Child. 2006, 73, 146-151.

90. Kärkkäinen, S.; Seppa, L.; Hausen, H. Dental check-up intervals and caries preventive measures received by adolescents in Finland. Community Dent. Health 2001, 18, 157-161.

91. Tickle, M.; Milsom, K.M.; King, D.; Blinkhorn, A.S. The influences on preventive care provided to children who frequently attend the UK General Dental Service. Br. Dent. J. 2003, 194, discussion 318. [CrossRef]

92. Nihtilä, A.; Widström, E. Heavy use of dental services among Finnish children and adolescents. Eur. J. Paediatr. Dent. 2009, 10, 7-12.

93. Wang, N.J.; Aspelund, G.Ø. Preventive care and recall intervals. Targeting of services in child dental care in Norway. Community Dent. Health 2010, 27, 5-11.

94. Sarmadi, R.; Gahnberg, L.; Gabre, P. Clinicians' preventive strategies for children and adolescents identified as at high risk of developing caries. Int. J. Paediatr. Dent. 2011, 21, 167-174. [CrossRef]

95. Masoe, A.V.; Blinkhorn, A.S.; Taylor, J.; Blinkhorn, F.A. Preventive and clinical care provided to adolescents attending public oral health services New South Wales, Australia: A retrospective study. BMC Oral Health 2014, 14, 142. [CrossRef]

96. Raindi, D.; Thornley, A.; Thornley, P. Explaining diet as a risk factor for periodontal disease in primary dental care. Br. Dent. J. 2015, 219, 497-500. [CrossRef]

97. Skinner, J.; Byun, R.; Blinkhorn, A. Utilization of public oral health services by New South Wales teenagers, 2004-05 to 2014-15. Aust. Dent. J. 2016, 61, 514-520. [CrossRef]

98. Demko, C.A.; Victoroff, K.Z.; Wotman, S. Concordance of chart and billing data with direct observation in dental practice. Community Dent. Oral Epidemiol. 2008, 36, 466-474. [CrossRef]

99. Wotman, S.; Demko, C.A.; Victoroff, K.; Sudano, J.J.; Lalumandier, J.A. A multimethod investigation including direct observation of 3751 patient visits to 120 dental offices. Clin. Cosmet. Investig. Dent. 2010, 2, 27-39. [CrossRef]

100. Threlfall, A.G.; Milsom, K.M.; Hunt, C.M.; Tickle, M.; Blinkhorn, A.S. Exploring the content of the advice provided by general dental practitioners to help prevent caries in young children. Br. Dent. J. 2007, 202, E9; discussion 148-149. [CrossRef]

101. Cashmore, A.W.; Noller, J.; Ritchie, J.; Johnson, B.; Blinkhorn, A.S. Reorienting a paediatric oral health service towards prevention: Lessons from a qualitative study of dental professionals. Heal. Promot. J. Aust. 2011, 22, 17-21. [CrossRef]

102. Ong, H.H.; Wan, C.C.; Gao, X. Interprofessional Collaboration in Addressing Diet as a Common Risk Factor: A Qualitative Study. J. Res. Interprof. Pract. Educ. 2015, 5. [CrossRef]

103. Lacey, K.; Pritchett, E. Nutrition Care Process and Model: ADA adopts road map to quality care and outcomes management. J. Am. Diet. Assoc. 2003, 103, 1061-1072. [CrossRef]

104. Boyd, L.D.; Hartman-Cunningham, M.L. Survey of diabetes knowledge and practices of dental hygienists. J. Dent. Hyg. 2008, $82,43$. 
105. Efurd, M.G.; Bray, K.K.; Mitchell, T.V.; Williams, K. Comparing the risk identification and management behaviors between oral health providers for patients with diabetes. J. Dent. Hyg. 2012, 86, 130-140. [PubMed]

106. Braithwaite, A.S.; Vann, W.F.J.; Switzer, B.R.; Boyd, K.L.; Lee, J.Y. Nutritional counseling practices: How do North Carolina pediatric dentists weigh in? Pediatr. Dent. 2008, 30, 488-495. [PubMed]

107. Curran, A.E.; Caplan, D.J.; Lee, J.Y.; Paynter, L.; Gizlice, Z.; Champagne, C.; Ammerman, A.S.; Agans, R. Dentists' attitudes about their role in addressing obesity in patients: A national survey. J. Am. Dent. Assoc. 2010, 141, 1307-1316. [CrossRef] [PubMed]

108. da Gomes, F.J.S.; Paula, A.B.P.; Curran, A.E.; Rodrigues, M.A.; Ferreira, M.M.; Carrilho, E.V.P. Portuguese Dentists' Attitudes Towards Their Role in Addressing Obesity. Oral Health Prev. Dent. 2016, 14, 13-20.

109. Clark, E.; Tuthill, D.; Hingston, E.J. Paediatric dentists' identification and management of underweight and overweight children. Br. Dent. J. 2018, 225, 657-661. [CrossRef]

110. Bennett, S. Reducing Dental Disease A Canadian Oral Health Framework. 2013. Available online: https://www.caphd.ca/sites/ default/files/FrameworkOctober\%202014\%20-\%20FINAL\%20English.pdf (accessed on 30 September 2021).

111. Saskatchewan Prevention Institute. Improving the Oral Health of Pregnant Women and Young Children: Opportunities for Oral Care and Prenatal Care Providers-A Saskatchewan Consensus Document. 2014. Available online: https://skprevention.ca/wpcontent/uploads/2016/07/2-804_Improving_Oral_Health_Consensus_Document.pdf?x98285 (accessed on 30 September 2021). 